\title{
Local Buckling Studies of Cold-formed Steel Compression Members at Elevated Temperatures
}

\author{
Shanmuganathan Gunalan ${ }^{1}$, Yasintha Bandula Heva ${ }^{2}$ and Mahen Mahendran ${ }^{3}$
}

\begin{abstract}
:
Cold-formed steel members have been widely used in residential and commercial buildings as primary load bearing structural elements. They are often made of thin steel sheets and hence they are more susceptible to local buckling. The buckling behaviour of cold-formed steel compression members under fire conditions is not fully investigated yet and hence there is a lack of knowledge on the fire performance of cold-formed steel compression members. Current cold-formed steel design standards do not provide adequate design guidelines for the fire design of cold-formed steel compression members. Therefore a research project based on extensive experimental and numerical studies was undertaken to investigate the local buckling behaviour of light gauge cold-formed steel compression members under simulated fire conditions. First a series of 91 local buckling tests was conducted at ambient and uniform elevated temperatures up to $700^{\circ} \mathrm{C}$ on cold-formed lipped and unlipped channels. Suitable finite element models were then developed to simulate the behaviour of tested columns and were validated using test results. All the ultimate load capacity results for local buckling were compared with the predictions from the available design rules based on AS/NZS 4600, BS 5950 Part 5, Eurocode 3 Parts 1.2 and 1.3 and the direct strength method (DSM), based on which suitable recommendations have been made for the fire design of cold-formed steel compression members subject to local buckling at uniform elevated temperatures.
\end{abstract}

Keywords: Cold-formed steel columns, Local buckling, Experiments, Finite element modelling, Elevated temperatures, Design rules.

Corresponding author's email address: m.mahendran@qut.edu.au

1 - Research Associate, Science and Engineering Faculty, Queensland University of Technology, Brisbane, QLD 4000, Email: s.gunalan@qut.edu.au

2 - Former PhD Researcher, Science and Engineering Faculty, Queensland University of Technology, Brisbane, QLD 4000, Email: deeson@gmail.com

3 - Professor, Science and Engineering Faculty, Queensland University of Technology, Brisbane, QLD 4000, Email: m.mahendran@qut.edu.au 


\subsection{Introduction}

In recent times the use of cold-formed steel construction has gained significant popularity in many countries due to the many advantages and benefits it offers. Cold-formed steel structures are made of thin-walled and light weight members and thus when exposed to elevated temperatures during fire events, their performance can deteriorate considerably. Cold-formed steel compression members are also susceptible to local, distortional, flexural and flexural-torsional buckling effects and hence their load bearing capacities are likely to be reduced significantly when exposed to elevated temperatures. For successful use of coldformed steel members in buildings without any fire damage, they should be protected or designed based on reliable fire design rules. Many cold-formed steel codes, AS/NZS 4600 [1], EC3 Part 1.3 [2], BS 5950 Part 5 [3] and AISI [4] give suitable design rules for coldformed steel columns subject to buckling effects at ambient temperature while BS 5950 Part 8 [5] and EC3 Part 1.2 [6] give design rules at elevated temperatures. The latter two elevated temperature design standards mainly focus on hot-rolled steel members and recommend the same guidelines for the design of cold-formed steel members with some limitations, despite the fact that the behaviour of cold-formed steel members is different from that of hot-rolled steel members. This leads to uneconomical designs for cold-formed steel structures. Many researchers have undertaken detailed studies on cold-formed steel members at elevated temperatures with an aim to develop suitable fire design rules. However, such studies have been limited to distortional, flexural and flexural-torsional buckling behaviour of cold-formed steel members at elevated temperatures [7-10]. Local buckling behaviour of cold-formed steel members at elevated temperatures has not been fully investigated and there is no well documented test data to develop design guidelines at elevated temperatures. Therefore a series of local buckling tests was carried out first on cold-formed steel short columns at ambient and elevated temperatures with three thicknesses $(0.95 \mathrm{~mm}, 1.9 \mathrm{~mm}$ and $1.95 \mathrm{~mm})$ and three grades (G250, G450 and G550).

Many different software packages are available to predict the structural behaviour of thinwalled members subjected to different actions. They can predict accurate results provided the relevant loading and boundary conditions and mechanical properties are modelled correctly. The major advantage of these analyses is the elimination of costly and time consuming physical testing. In this research, ABAQUS Standard Version 6.7 was used to investigate the behavior of tested cold-formed steel compression members subject to local buckling at 
ambient and uniform elevated temperatures. Elevated temperature tests were simulated by using appropriately reduced mechanical properties. The developed finite element models were validated using the load-deflection curves, failure mode and ultimate loads obtained from tests.

This paper presents the details of the experimental study into the local buckling behaviour and capacities of cold-formed steel columns at ambient and uniform elevated temperatures. It also presents the details of finite element models developed to investigate the local buckling behaviour of cold-formed steel columns and their validation using test results. Finally, it compares the ultimate load capacities from both finite element analyses and tests obtained at elevated temperatures with those obtained from existing cold-formed steel design standards.

\subsection{Experimental Study}

Two series of experimental studies were conducted to investigate the behaviour of coldformed steel compression members subject to local buckling at ambient temperature and different uniform elevated temperatures up to $700^{\circ} \mathrm{C}$. Suitable test sections and thicknesses were selected based on the available literature and the standard sections and thicknesses commonly used in structural and architectural applications. The two most commonly used sections, unlipped and lipped channels, were selected (referred to as Types A and B in Figure 1). Thicknesses of light gauge cold-formed steel vary from of $0.42 \mathrm{~mm}$ to $3 \mathrm{~mm}$. Therefore three nominal thicknesses of $0.95,1.90$ and $1.95 \mathrm{~mm}$ were selected to represent the light gauge cold-formed steel domain. Cold-formed steel members are available in two strength grades, namely low and high strength grades. Therefore one low strength (G250) and two high strength (G450 and G550) grades were selected with the chosen thicknesses (total of eight sections in Table 1).

These analyses were then extended to elevated temperatures using the reduced mechanical properties of $0.95 \mathrm{~mm}, 1.90 \mathrm{~mm}$ and $1.95 \mathrm{~mm}$ thick cold-formed steels from Dolamune Kankanamge and Mahendran [11]. The first test series was conducted at ambient temperature and the specimens were loaded using the Tinius Olsen testing machine in the QUT structural laboratory. The second test series at elevated temperatures was conducted inside an electrical furnace and the specimens were loaded using the special loading shafts attached to the Tinius Olsen testing machine. 


\subsection{Local Buckling Tests at Ambient Temperature}

The first series of experimental study was conducted at room temperature $\left(20^{\circ} \mathrm{C}\right)$. For the selected test sections, a slender web was selected for lipped channel sections while slender flanges were selected for unlipped channel sections to ensure that local buckling occurred in these elements. Elastic local buckling analyses were undertaken using CUFSM and ABAQUS and the results were used to select the dimensions of each test section to ensure the occurrence of local buckling during ambient temperature tests. Some buckling plots obtained in these analyses are shown in Figures 2 (a) and (b). Distortional buckling can be observed in lipped channels. Therefore the web width was further increased to avoid any interaction of local and distortional buckling modes. Table 1 shows the selected web, flange and lip dimensions of test sections. Half wave length for each buckling mode can be identified from the buckling plots of CUFSM. Specimen lengths were then selected as a multiple of half wave lengths for local buckling. In addition to the above length, an additional $20 \mathrm{~mm}$ length was included to either ends to minimize the effect of end supports. Table 1 shows the buckling half wave lengths (l) and the chosen specimen lengths for test sections.

External dimensions and thicknesses of test specimens were measured using a vernier calliper and a micrometer screw gauge (Tables 2 and 3). It is common practice to use the base metal thickness in structural calculations. The base metal thickness was obtained by removing the coating of cold-formed steel specimens by immersing them in diluted hydrochloric acid. Thickness measurements were taken at three different locations for each specimen. Table 2 gives the average base metal thickness of each steel grade and thickness used in the tests. As noted in Table 3 a total of 24 ambient temperature tests were conducted. All the specimens were labelled according to the grade, thickness, test temperature and type of specimen as shown in the table.

Ambient temperature tests were conducted using the Tinius Olsen testing machine in the Structural Laboratory as shown in Figure 3(a). Test specimens were located at the centre of a thicker steel plate, which was located at the base of the testing machine. A similar size steel plate was fixed to the cross-head of the machine and the specimen was placed between these two steel plates and loaded in axial compression to failure. During the tests, axial shortening and out-of-plane displacements of specimens were recorded in addition to the applied load. 
Out-of-plane displacements were measured at the middle of test specimens using $10 \mathrm{~mm}$ LVDTs attached to them. Axial shortening of the specimens was measured using the inbuilt LVDT of the machine. In addition to this, an independent $5 \mathrm{~mm}$ LVDT was used (Figure 3(b)) to measure axial shortening (Figure 4). All the LVDTs and the load channel were connected to a data logger system. All the other load-deflection curves are given in Bandula Heva [12]. Table 3 presents the ultimate load from each specimen while Figure 3(b) shows the typical failure modes of Type A and B specimens.

\subsection{Local Buckling Tests at Elevated Temperatures}

The second series of tests was conducted to investigate the behaviour of cold-formed steel short columns subjected to local buckling at uniform elevated temperatures. The same coldformed steel section types, thicknesses and grades tested at ambient temperature were used in elevated temperature tests. Since cold-formed seel members lose their compressive strength significantly (approximately by $90 \%$ ) at temperatures higher than $700^{\circ} \mathrm{C}[10]$, these tests were limited to $700^{\circ} \mathrm{C}$. As reported in [11], a significant reduction in yield strength occurred after $300^{\circ} \mathrm{C}$ (see Figure 13). Therefore tests were conducted at every $100^{\circ} \mathrm{C}$ intervals for temperatures greater than $300^{\circ} \mathrm{C}$. In addition to the above temperatures, tests were also conducted for some sections at $100^{\circ} \mathrm{C}$ and $200^{\circ} \mathrm{C}$ to understand the local buckling behaviour at lower elevated temperatures.

All the selected specimens were analysed to find the elastic buckling loads and buckling modes at pre-selected temperatures $\left(100\right.$ to $\left.700^{\circ} \mathrm{C}\right)$ using CUFSM and ABAQUS with the reduced mechanical properties reported in [11]. Elastic local buckling analysis results were used to finalise the dimensions of each test section to ensure the occurrence of local buckling during both ambient and elevated temperature tests. Buckling plots of all the selected sections at ambient and elevated temperatures were used to understand the variation of elastic buckling loads with increasing temperatures. External dimensions and thicknesses of specimens used in elevated temperature tests were measured using a vernier calliper and a micrometer screw gauge (Tables 4 and 5). As noted in these tables a total of 64 elevated temperature tests was conducted.

Test specimens were heated to the required uniform elevated temperature in an electric furnace (Figure 5) and then loaded in axial compression until failure while maintaining the 
temperature. A special loading set-up located inside the furnace was then used to load the specimens using Tinius Olsen Testing Machine. Four glow bars fitted to the furnace heated the specimens while a micro-computer based temperature control system controlled the preset temperature and heating rate. A maximum heating rate of up to $30^{\circ} \mathrm{C} / \mathrm{min}$ can be achieved with this furnace. The temperature at the centre of glow bars was slightly less than the pre-set temperature. Hence the furnace temperature was set slightly higher than the required temperature and a thermometer was located at the centre to monitor the specimen temperature. In this way, the specimen temperature was measured with less than $1 \%$ error at higher temperatures above $400^{\circ} \mathrm{C}$ and $2 \%$ error below $300^{\circ} \mathrm{C}$. Two holes measuring $43 \mathrm{~mm}$ in diameter were provided at the top and bottom of the furnace to insert the loading shafts. An observation window located on one side of the furnace was used to observe the test specimen and its behaviour during loading. Special openings on the furnace were used to insert an LVDT and a thermocouple to the specimen. They were used to measure the out-of-plane deflection and temperature of the specimen. Another thermocouple was permanently fixed to the furnace, which monitored the temperature inside the furnace and communicated with the microcomputer system in controlling the furnace temperature.

A loading arrangement was made using two loading shafts made of 253MA stainless steel for use at elevated temperatures. For the bottom loading shaft, a $40 \mathrm{~mm}$ diameter circular bar of grade $253 \mathrm{MA}$ stainless steel was fitted to $25 \mathrm{~mm}$ thick and $130 \mathrm{~mm}$ diameter plate of the same grade stainless steel. Other end of the rod was threaded into a rigid steel plate. A similar arrangement was made to the top loading shaft. The bottom loading shaft was located on the flat base of Tinius Olsen Testing Machine while the top loading shaft was fixed to the cross head of the machine through a rigid plate. Both shafts were tightened using locknuts. Special care was taken to align the loading shafts to avoid any eccentric loading. For this purpose, three $10 \mathrm{~mm}$ holes were drilled in both the top and bottom loading plates at the same locations and three specially made steel rods of $10 \mathrm{~mm}$ were fitted to the top loading plate. The top loading shaft with three rods was then lowered so that these rods moved through the holes. The bottom loading shaft was given some fine adjustments until the three small rods could move within the holes without any friction (Figure 5 (c)).

To assess the accuracy of the loading set-up, four Type A specimens of $1.9 \mathrm{~mm} \mathrm{G} 450$ and $1.95 \mathrm{~mm} \mathrm{G} 250$, which gave the highest buckling capacity at the ambient temperature, were 
tested using this loading set-up attached to the furnace. They were also tested without this elevated temperature loading set-up and the furnace. Comparison of their results ensured the accuracy of the loading set-up as shown in Table 6.

For the elevated temperature tests, test specimen was first placed between the loading plates. It is important to avoid any loading eccentricity. Therefore the loading axis was made to coincide with the geometric centre of the section. The geometry of each section was drawn on the plate of the bottom loading shaft and the specimen was then placed with its geometric centre at the centre of the plate. The specimen was then heated to the required temperature and then allowed another 20 minutes to ensure a uniform temperature throughout the specimen prior to loading. During the heating phase the axial compression load on the specimen was carefully monitored. Since the thermal expansion of the specimen and the loading shafts induced a compression load, the machine cross-head was raised slowly so that an initial load of $0.1 \mathrm{kN}$ was maintained. This initial load was applied to prevent the lateral movement of specimen when the out-of-plane displacement measuring LVDT was inserted. Exact specimen temperature was measured by using a portable thermocouple inserted into the furnace. Finally the load was applied until failure by the Tinius Olsen testing machine. Figure 6 shows the typical failure modes of Types A and B specimens at elevated temperatures whereas Tables 4 and 5 give the ultimate loads of Types A and B specimens at elevated temperatures, respectively. Figure 7 shows the typical load-deflection curves for Type B specimens at $300^{\circ} \mathrm{C}$ while Bandula Heva and Mahendran [12] gives the other load-deflection curves.

\subsection{Development of Finite Element Models}

\subsection{Selection of Element Type and Size}

Shell type elements were selected for the simulations because cold-formed steel members are made of thin steel sheets. Numerous shell element types are available in the finite element simulation using ABAQUS. They are S4, S4R, S4R5, S8R5 and S9R5. All these element types were considered in the simulation of G550-0.95-20-A specimen in order to select the most suitable element type. Both elastic buckling and nonlinear analyses were conducted with each element type. Suitable geometric imperfections were applied to the lowest Eigen mode while residual stresses were also included in the nonlinear analyses. Axial compression load versus axial shortening curves were obtained for each element type and compared with 
those obtained from tests in Figure 8. It can be seen that all the element types provided accurate simulations of the chosen test specimen up to the ultimate load level. Higher order element types need more memory and processing time while results are of the same order compared with four node element types. Therefore the latter was selected. S4 element type needs more memory and processing time than the other elements with four nodes. For the small local buckling models the difference in processing time is not significant while memory requirement is not a critical issue for these models using the latest computers with large memory capacities. Therefore S4 element type was selected in this research.

Element size of the model is also an important factor in FEA. Finer mesh gives more accurate results at the expense of increased memory and processing time requirements. Therefore a convergence study was conducted for G550-0.95-20-A specimen with various mesh sizes from $1 \mathrm{~mm} \times 1 \mathrm{~mm}$ to $9 \mathrm{~mm} \times 9 \mathrm{~mm}$ to determine the optimum element size. Figure 9 compares the effect of element size on the elastic buckling and ultimate loads of G550-0.9520-A specimens. Since the variation of elastic buckling and ultimate loads for the element sizes less than $3 \mathrm{~mm} \times 3 \mathrm{~mm}$ mesh is negligible, $3 \mathrm{~mm} \times 3 \mathrm{~mm}$ element size was selected in this research.

\subsection{Loading and Boundary Conditions}

For accurate simulations it is important to use accurate boundary conditions that reflect the end supports used in the experimental tests. In the tests, both ends of the columns were fixed against rotation while the top end was allowed to move axially. Therefore only axial translation was allowed to the nodes at the upper end of the finite element model. At the lower end, all the translation and rotational movements were restrained. These boundary conditions were applied to the independent node of the rigid fixed MPC (Multi Point Constraint). Dependent nodes are connected to the independent node using rigid beams and all the six structural degrees of freedoms are rigidly attached to each other. In this model, the independent node was located at the geometric centre of the cross-section. Dependent nodes are the perimeter nodes at the end surface of the model. Since the element size was selected as $3 \mathrm{~mm} \times 3 \mathrm{~mm}$, the distance between the dependent nodes was small. Hence this MPC acted as a rigid surface that was rigidly connected to the end of the columns. The load was applied to the independent node at the geometric centre of the rigid fixed MPC located at the upper end (Figure 10). 


\subsection{Geometric Imperfections}

Geometric imperfections of light gauge cold-formed steel members play a vital role in FEA since their magnitudes can be high in comparison with the member thickness. The ultimate load of cold-formed steel members can thus be significantly affected. Therefore suitable geometric imperfections should be included in the nonlinear analyses to initiate the appropriate buckling deformations. Local imperfections affect the local or distortional buckling (section) capacities and are expressed in terms of section dimensions and thickness. Many researchers used the measured imperfections in their finite element simulations $[13,14]$. Some researchers used the section thickness as the imperfection value for thin coldformed lipped channels $[15,16]$. Initial imperfection of stiffened elements subjected to local buckling is also taken as a function of web width. For example, Outinen and Myllymaki [17] and Feng et al. [18] used $h / 200$, where $h$ is the width of stiffened element. Schafer and Pekoz [19] recommended the initial imperfection of web elements of lipped channel members to be taken as a function of the width of web $(w), 0.006 w$, or an exponential function based on the thickness $(t)$ of the web, 6te $e^{-2 t}$. Many researchers [13,19] consider the thickness as the imperfection for thin unlipped (plain) channels. Camotim et al. [20] used $0.15 t$ as the imperfection value for both local and distortional buckling. After detailed considerations of all the above, the imperfection models proposed by Schafer and Pekoz [19] for lipped channels $\left(d_{1}=6 t e^{-2 t}\right)$ and Camotim et al. [20] for plain channels $\left(d_{2}=0.15 t\right)$ were used (see Figure 10(b)).

\subsection{Residual Stresses}

Schafer and Pekoz [19] proposed suitable flexural residual stress models for both roll-formed sections and press-braked sections as a percentage of yield stress. Their models have higher residual stresses at the corners. But the press-braked specimens used in this research have sharp corners, and the corner radius was negligibly small. Therefore the corner regions with higher residual stresses due to press braking can be neglected. Flexural residual stresses in the flanges were also assumed to be the same as that of web for lipped channels because the amount of cold working involved is considered to be the same in the manufacturing process. Hence the residual stress model proposed by Ranawaka and Mahendran [21] was used in this research. However, the difference between the ultimate load capacities obtained with and 
without residual stresses was less than $1 \%$. Also the residual stresses reduce with increasing temperatures. Hence it was decided to ignore the effect of residual stresses in this research.

\subsection{Mechanical Property Model}

Mechanical properties are characterized by elastic modulus, stress-strain relationship and Poisson's ratio. There are two stress-strain models (Figure 11), namely elastic-perfect plastic and strain hardening models used in FEA. The first model assumes a constant yield stress in the plastic range whereas the second model includes strain hardening in the inelastic range. The stress-strain curves from tensile coupon tests show the presence of strain hardening behaviour. Therefore accurate results could be obtained by using the more accurate strain hardening model. This is particularly important for elevated temperature test simulations.

The use of elastic-perfect plastic model is simple. Some researchers use this model for ambient temperature test simulations. In order to compare the mechanical property models, local buckling behaviour of G550-0.95-20-A and G550-0.95-500-A specimens was simulated based on elastic-perfect plastic and strain hardening models. Since a clear yielding region was not observed in the stress-strain curves, $0.2 \%$ proof stress was considered as the yield stress. Tensile coupon tests give the nominal stress-strain curves. ABAQUS require stress-strain relationship in terms of true stress and logarithmic plastic strain. True stress and logarithmic plastic strain values of selected points on a stress-strain curve were obtained from Equations 1 (a) and (b) using the nominal stress and strain values at those points.

$$
\begin{aligned}
& \sigma_{\text {true }}=\sigma_{\text {nom }}\left(1+\varepsilon_{\text {nom }}\right) \\
& \varepsilon_{\ln }^{p l}=\ln \left(1+\varepsilon_{\text {nom }}\right)-\frac{\sigma_{\text {true }}}{E}
\end{aligned}
$$

Elastic buckling analyses were conducted first, which were followed by non-linear analyses based on the two mechanical property models. S4 element type was used in the simulations with both geometric imperfections and residual stresses. The load-deflection curves obtained from these analyses were compared with those from experimental tests at ambient and elevated $\left(500^{\circ} \mathrm{C}\right)$ temperatures (Figure 12). This comparison shows that the use of strain hardening model gave a better agreement with test results. In the elevated temperature case the test curve also includes the shortening of the top and bottom loading shafts. Since the 
mechanical properties of loading shafts are not available at elevated temperatures, a suitable correction to the test curve was not included. If this correction was made, the test curve would agree more closely with that based on the strain hardening model. Therefore it can be concluded that strain hardening mechanical property model must be used to simulate the local buckling behaviour of cold-formed steel columns, particularly at elevated temperatures.

The ambient temperature mechanical properties of G550-0.95 mm and G250-0.95 mm thick cold-formed steels were obtained from Ranawaka and Mahendran [21] while those of G450$1.90 \mathrm{~mm}$ and G250-1.95 mm were obtained from Dolamune Kankanamge and Mahendran [11]. Table 7 gives the mechanical property values for these selected steel thicknesses and strength grades. The measured mechanical properties at elevated temperatures for G450-1.90 $\mathrm{mm}$ and G250-1.95 mm thick cold-formed steels were obtained from [11]. However, for G550-0.95 $\mathrm{mm}$ and G250-0.95 $\mathrm{mm}$ thick cold-formed steels, they were obtained from Equations 2 to 4 given in [11] since their measured values are not available.

Yield strength reduction factors for G550-0.95 mm thick cold-formed steels,

$$
\begin{array}{ll}
\frac{f_{y T}}{f_{y 20}}=-0.00016 T+1.0003 & 20^{\circ} C \leq T \leq 200^{\circ} C \\
\frac{f_{y T}}{f_{y 20}}=0.97-\frac{(T-200)^{1.81}}{58500} & 200^{\circ} C<T<600^{\circ} C \\
\frac{f_{y T}}{f_{y 20}}=-0.00037 T+0.3363 & 600^{\circ} C \leq T \leq 800^{\circ} C
\end{array}
$$

Yield strength reduction factors for G250-0.95 mm thick cold-formed steels,

$$
\begin{array}{ll}
\frac{f_{y T}}{f_{y 20}}=-0.0007 T+1.014 & 20^{\circ} C \leq T \leq 200^{\circ} C \\
\frac{f_{y T}}{f_{y 20}}=3.7-\frac{(T-74)^{0.15}}{0.736} & 200^{\circ} C<T \leq 800^{\circ} C
\end{array}
$$

Elasticity modulus reduction factors for G550-0.95 and G250-0.95 mm thick coldformed steels, 


$$
\begin{array}{ll}
\frac{E_{T}}{E_{20}}=1 & 20^{\circ} C \leq T \leq 100^{\circ} C \\
\frac{E_{T}}{E_{20}}=-0.0013 T+1.1297 & 100^{\circ} C<T \leq 800^{\circ} C
\end{array}
$$

The Ramberg Osgood stress-strain model and appropriate parameters proposed by Ranawaka and Mahendran [21] and Dolamune Kankanamge and Mahendran [11] are given by Equations 5 and 6. Dolamune Kankanamge and Mahendran [11] proposed 0.86 for $\beta$ for high strength cold-formed steels, but 1.5 for low strength cold-formed steels.

$$
\varepsilon_{T}=\frac{f_{T}}{E_{T}}+\beta\left(\frac{f_{y, T}}{E_{T}}\right)\left(\frac{f_{T}}{f_{y, T}}\right)^{\eta_{T}}
$$

\section{For G550 steel}

$$
\eta_{T}=-3.05 \times 10^{-7} T^{3}+0.0005 T^{2}-0.2615 T+62.65320^{\circ} \mathrm{C} \leq T \leq 800^{\circ} \mathrm{C}
$$

\section{For G250 steel}

$$
\eta_{T}=0.000138 T^{2}-0.085468 T+19.212 \quad 350^{\circ} C \leq T \leq 800^{\circ} C
$$

Elevated temperature mechanical properties $\left(f_{y T}\right.$ and $\left.E_{T}\right)$ were used in the above equations to derive the stress-strain curves at the required temperatures for use in FEA. The Ramberg Osgood stress-strain model cannot be used for the low strength cold-formed steels at lower temperatures because they show a yield pattern in the stress-strain curves. Therefore the elastic-perfect plastic mechanical property model was used in the FEA of cold-formed steel columns at lower temperatures up to $300^{\circ} \mathrm{C}$. Figure 13 shows the stress-strain curves at elevated temperatures for G550-0.95 mm and G250-0.95 steels.

\subsection{Analysis Methods}

Test specimens were analysed by using ABAQUS to determine the elastic buckling and ultimate loads. MSC/PATRAN was used as a pre-processor to create the input files and as a post-processor to read the results. Two types of analyses were conducted using ABAQUS. Elastic buckling analyses were used to determine the elastic buckling loads and modes while nonlinear analyses were used to determine the ultimate loads and deformations. Initial 
geometric imperfections were included into the appropriate eigen buckling mode obtained from elastic buckling analyses. Nonlinear analyses were conducted using the modified Riks method to find the ultimate compression load.

\subsection{Validation of Finite Element Models}

For this purpose, a total of eight finite element models of tested specimens were simulated at ambient and uniform elevated temperatures. These eight models consisted of three thicknesses (0.95 $\mathrm{mm} 1.90 \mathrm{~mm}$ and $1.95 \mathrm{~mm})$, three grades (G250, G450 and G550) and two section types (stiffened and unstiffened). They were validated using the load-shortening curves, ultimate loads and failure modes from tests and FEA. Due to an experimental recording error, test results of G250-0.95A specimens could not be used in this comparison.

Axial compression load versus axial shortening curves from the experimental tests and FEA are shown in Figures 14 (a) and (b), which show good agreement. Both elastic buckling and ultimate loads were obtained from FEA. However, the elastic buckling load could not be measured accurately during testing. Therefore only the ultimate load was used in the comparisons. Tables 8 and 9 show the comparison of ultimate loads from tests and FEA for Types $\mathrm{A}$ and $\mathrm{B}$ specimens, respectively. These tables also present the mean values and associated coefficients of variation for the ratio of ultimate load from test to FEA at different elevated temperatures. The mean values for different cases (steel grade, thickness and type) remained between 0.97 and 1.10, which indicates a good agreement between test and FEA predictions. Accuracy of the developed models was also assessed by comparing the failure modes from FEA and tests. Figures 15 (a) and (b) show that the failure modes of Types A and B specimens from FEA and tests are very similar. In summary, by considering the ultimate loads, load-shortening curves and failure modes, it can be concluded that the developed finite element models are able to accurately simulate the local buckling behaviour of cold-formed steel compression members at ambient and elevated temperatures. The use of accurate elevated temperature mechanical properties including stress-strain curves (Figure 13) was a critical factor contributing to such accurate simulations. 


\subsection{Comparison of Test and FEA Results with Predictions from the Current Design}

\section{Standards}

\subsection{Design Standards}

Many cold-formed steel design codes, AS/NZS 4600 [1], Eurocode 3 Part 1.3 [2], BS 5950 Part 5 [3] and AISI [4], give design rules for cold-formed steel short columns subjected to local buckling at ambient temperature which recommend the use of the well-known effective with method for local buckling. However, AS/NZS 4600 [1] and AISI [4] give identical design rules for local buckling and hence only AS/NZS 4600 [1] is mentioned in this paper. Schafer [7] proposed a new method called the Direct Strength Method (DSM) that eliminates the tedious calculations of effective with of each plate element in the section. This method is now recommended as an alternative method by AS/NZS 4600 [1] and AISI [4]. Although the above design codes were originally developed for calculating the local buckling capacities at ambient temperature conditions, the same design equations were used in this research to calculate the local buckling capacities at elevated temperatures, simply by using the appropriately reduced mechanical properties. The mechanical properties used in the finite element modelling were also used in the design calculations.

The fire code Eurocode 3 Part 1.2 [6] recommends the use of effective widths at ambient temperature with the yield stress at elevated temperature. Therefore the effective areas were calculated based on ambient temperature properties using Eurocode 3 Part 1.3 [2]. However, other calculations were based on the reduced mechanical properties at elevated temperatures. The DSM needs the relevant elastic buckling load from a rational buckling analysis. Therefore the elastic buckling loads at elevated temperatures were obtained from FEA and used in these calculations. Appendix A presents the details of relevant design rules from AS/NZS 4600, BS 5950 Part 5, Eurocode 3 Parts 1.2 and 1.3 and DSM.

\subsection{Comparison of Test and FEA Results with Code Predictions}

Tables 10 and 11 compare the ultimate loads from tests and FEA with predictions from various design standards for lipped and unlipped channel sections (Types A and B), respectively. All the design standards predicted the ultimate loads conservatively at ambient temperature. Among them the DSM predicted the ultimate loads more accurately at ambient temperatures compared to other design standards. 
At elevated temperatures, AS/NZS 4600, BS 5950 Part 5, Eurocode 3 Parts 1.2 and 1.3 were found to be conservative in predicting the local buckling capacities of cold-formed steel columns. The FEA to predicted ratios were more than one in most cases that resulted in higher values of capacity reduction factor $(\phi)$ compared to its recommended value of 0.85 . However, the DSM was found to be unconservative for low grade steel sections $(\phi<0.85)$.

Figures 16 (a) and (b) compare the ratio of FEA/Predicted ultimate load ratios at elevated and ambient temperatures $\left((\text { FEA/Predicted })_{\mathrm{T}} /(\mathrm{FEA} / \text { Predicted })_{20}\right)$ for two lipped channel sections. These figures eliminate the differences in the ambient temperature FEA/Predicted ultimate load ratios, and thus allow us to assess the ability of different design rules in predicting the elevated temperature capacities. These figures show that the predictions of AS/NZS 4600, BS 5950 Part 5, Eurocode 3 Part 1.3 and DSM agree reasonably well among them. On the other hand the predictions of Eurocode 3 Part 1.2 are significantly different to others due to the fact that this standard recommends the use of effective area at ambient temperature for elevated temperature capacity calculations. The inaccuracy of local buckling capacity prediction by Eurocode 3 Part 1.2 is also observed in Tables 10 and 11 (conservative with FEA/Predicted ratios $>1.40$ ). In contrast, the use of effective area at elevated temperatures using Eurocode 3 Part 1.3 design rules led to good agreement with other design standards and FEA. Hence this research study recommends the use of effective area at elevated temperatures in predicting the local buckling capacities of cold-formed steel columns at elevated temperatures.

The ultimate strength behaviour of cold-formed steel columns at elevated temperature is influenced by the reduced yield strength and elastic modulus and their relative rate of reduction, ie. $\mathrm{k}_{\mathrm{fyT}} / \mathrm{k}_{\mathrm{ET}}=\left(\mathrm{f}_{\mathrm{yT}} / \mathrm{f}_{\mathrm{y} 20}\right) /\left(\mathrm{E}_{\mathrm{T}} / \mathrm{E}_{20}\right)$, and the level of non-linearity in the elevated temperature stress-strain curves. For the accurate prediction of local buckling capacities at elevated temperatures, the curves from the various design standards and DSM shown in Figures 16 (a) and (b) should be closer to one. However, this agreement is poor at $600^{\circ} \mathrm{C}$ and $700^{\circ} \mathrm{C}$ for high grade steel sections and at $500^{\circ} \mathrm{C}$ and $600^{\circ} \mathrm{C}$ for low grade steel sections. The variation of $\mathrm{k}_{\mathrm{fy}} / \mathrm{k}_{\mathrm{ET}}$ is also plotted for low and high grade steels in Figures 16 (a) and (b) and it is interesting to note that the ultimate load ratio predicted by the design standards follow the trend of $\mathrm{k}_{\mathrm{fy} \mathrm{T}} / \mathrm{k}_{\mathrm{ET}}$. It is noted that a poor agreement in the ratio of $(\text { FEA/Predicted })_{\mathrm{T}} /(\text { FEA/Predicted })_{20}$ was observed when the $\mathrm{k}_{\mathrm{fyT}} / \mathrm{k}_{\mathrm{ET}}$ ratio deviates from unity. This demonstrates the importance of including the variations of $\mathrm{k}_{\mathrm{fy}} / \mathrm{k}_{\mathrm{ET}}$ ratio in the 
design calculations. The use of reduced elevated temperature mechanical properties via the slenderness ratio parameter $\left(\lambda_{\mathrm{T}}\right.$ - see Appendix A) includes the effects of $\mathrm{k}_{\mathrm{fy}} / \mathrm{k}_{\mathrm{ET}}$ variations in both the effective width and DSM based design calculations, but none of them include the effects of nonlinear stress-strain behaviour.

Figures 17 (a) and (b) show the comparison of FEA results with DSM design curve for the two types of sections made of low and high strength steels. Although the nonlinear stressstrain characteristics at elevated temperatures affects the predictions of all the design standards, the influence of this can only be shown for DSM. FEA results agreed well with the DSM design curve up to $200^{\circ} \mathrm{C}$ for low grade steel sections for which an elastic perfect plasticity model was used in FEA. Nonlinear stress-strain curves were included in FEA for all the temperatures of high grade steels and for temperatures above and including $300^{\circ} \mathrm{C}$ for low grade steels. Figure 17 clearly shows that the current DSM based design rule is unable to accurately predict the local buckling capacities of lipped and unlipped channel sections at elevated temperatures. The nonlinearity of stress-strain curves is more significant in low grade steels than in high grade steels as reported in [11] (see also Figure 13). This resulted in more scatted points for low grade steel sections compared to high grade steel sections in Figure 17.

In summary this section has shown that the current ambient temperature design rules (AS/NZS 4600, BS 5950 Part 5 and Eurocode 3 Part 1.3) can be used to conservatively predict the local buckling capacities at elevated temperatures provided appropriately reduced mechanical properties are used. However, the DSM leads to unconservative predictions for low grade steel sections. Further refinements are needed to the current design rules by including the effects of non-linear stress-strain characteristics. One may argue that the deviations are within the acceptable range. It may be true for the cold-formed steel sections reported in this paper. However, this paper recommends further study on the prediction of local buckling capacities of cold-formed steel columns by including the effects of non-linear stress-strain characteristics at elevated temperatures via the DSM based design rules.

\subsection{Conclusions}

Local buckling behaviour and strength of cold-formed steel compression members was investigated using both laboratory tests and finite element analyses at ambient and uniform 
elevated temperatures. Lipped and unlipped channel sections with thinner $(0.95 \mathrm{~mm})$ and comparatively thicker $(1.90 \mathrm{~mm}$ and $1.95 \mathrm{~mm})$ steels made of both low and high grade steels were selected. A total of 27 ambient temperature tests and 64 elevated temperature tests were conducted. Finite element models were also developed to simulate the local buckling behaviour of lipped and unlipped channels under axial compression. The developed finite element models were validated using the ultimate loads, failure modes and load-deflection curves from the experimental tests. Test and finite element analysis results were then compared with the predictions of cold-formed steel design standards with appropriately reduced mechanical properties. This paper has shown that ambient temperature design guidelines can be safely used to predict the local buckling capacities at uniform elevated temperatures using appropriately reduced mechanical properties. The fire code Eurocode 3 Part 1.2 recommends the use of effective area at ambient temperature. This resulted in too conservative predictions at elevated temperatures and hence this study recommends the use of effective area at elevated temperatures in predicting the local buckling capacities of coldformed steel columns at elevated temperatures. The accuracy of the current design rules can be further improved by incorporating the effects of non-linear stress-strain characteristics at elevated temperatures.

\section{Acknowledgements}

The authors would like to thank Australian Research Council for providing the financial support and Queensland University of Technology for providing the necessary facilities and support to conduct this research project.

\section{References}

[1] Standards Australia (SA), (2005), Cold-formed steel structures, AS/NZS 4600, Sydney, Australia.

[2] European Committee for Standardization (ECS), (2006), Eurocode 3: Design of steel structures. Part 1.3: General rules - Supplementary rules for cold-formed members and sheeting, Brussels, Belgium. 
[3] British Standards Institution (BSI), 1998, British Standard 5950: Structural use of steelwork in buildings, Part 5: Code of practice for design of cold-formed thin gauge sections, London, UK.

[4] American Iron and Steel Institute (AISI), (2007), Specifications for the cold-formed steel structural members, Cold-formed Steel Design Manual, Washington, USA.

[5] British Standards Institution (BSI), 2005, British Standard 5950: Structural use of steelwork in Buildings, Part 8: Code of practice for fire resistant design, London, UK.

[6] European Committee for Standardization (ECS), (2005), Eurocode 3: Design of steel structures. Part 1.2: General rules - Structural fire design, Brussels, Belgium.

[7] Schafer, B.W. (2001), Thin-walled column design considering local, distorsional and euler buckling, Proceeding of the Structural Stability Research Council Annual Stability Conference, Ft. Lauderdale, F1 419-438.

[8] Gunalan, S. and Mahendran, M. (2013), Improved design rules for fixed ended coldformed steel columns subject to flexural-torsional buckling. Thin-Walled Structures, Vol. 73, pp. $1-17$

[9] Gunalan, S., Bandula Heva, Y. and Mahendran, M. (2014), Flexural-torsional buckling behaviour and design of cold-formed steel compression members at elevated temperatures, Engineering Structures, Vol. 79, pp. 149-168.

[10] Ranawaka, T. and Mahendran, M. (2009), Distortional buckling tests of cold-formed steel compression members at elevated temperatures, Journal of Constructional Steel Research, Vol. 65, Issue 2, pp. 249-259.

[11] Dolamune Kankanamge, N. and Mahendran, M. (2011), Mechanical properties of coldformed steels at elevated temperatures, Thin-Walled Structures, Vol. 49, pp. 26-44.

[12] Bandula Heva, Y. and Mahendran, M. (2012), Flexural-torsional buckling tests of cold-formed 
steel compression members at elevated temperatures, Steel and Composite Structures, Vol. 14, pp. 205-227.

[13] Ranawaka, T. and Mahendran, M. (2010), Numerical modelling of light gauge cold-formed steel compression members subjected to distortional buckling at elevated temperatures, ThinWalled Structures, Vol. 48, pp. 334-344.

[14] Dubina, D. and Ungureanu, V. (2002), Effect of imperfections on numerical simulation of instability behaviour of cold-formed steel members, Journal of Thin-Walled Structures, Vol. 40, Issue 3, pp.239-262.

[15] Feng, M., Wang, Y.C. and Davies, J.M. (2003), Structural behaviour of thin-walled short steel channel columns at elevated temperatures. Part 2: Design calculations and numerical analyses, Thin-Walled Structures, Vol. 41, Issue 6, pp. 571-594.

[16] Chen, J. and Young, B. (2007), Cold-formed steel lipped channel columns at elevated temperatures, Engineering Structures, Vol. 29, Issue 10, pp.2445-2456.

[17] Outinen, T.A. and Myllymaki, J. (1995), The local buckling of rhs members at elevated temperatures, VIT Research Notes 1672, Technical Research Centre, Finland.

[18] Feng, M., Wang, Y.C. and Davies, J.M. (2004), A numerical imperfection sensitivity study of cold-formed thin-walled tubular steel columns at uniform elevated temperatures, Thin-Walled Structures, Vol. 42, pp. 533-555.

[19] Schafer, B.W. and Pekoz, T. (1998), Computational modelling of cold-formed steel: characterising geometric imperfections and residual stresses, Journal of Constructional Steel Research, Vol. 47, pp. 193-210.

[20] Camotim, D., Silvestre, N., Goncalves, R. and Dinis, P.B. (2006), GBT-based structural analysis of thin-walled members: Overview, Recent progress and future developments, Advances in Engineering Structures, Mechanics and Construction, pp. 187-204. 
[21] Ranawaka, T. and Mahendran, M. (2009), Experimental study of the mechanical properties of light gauge cold-formed steels at elevated temperatures, Fire Safety Journal, Vol. 44, Issue 2, pp. 219-229.

\section{Appendix: Design Rules - Concentrically Loaded Compression Members}

\section{AISI, AS/NZS 4600 and BS 5950 Part 5}

$N_{s T}=A_{e T} f_{y T}$

where

$N_{S T}$ is the nominal section capacity of the member in compression at elevated temperature $T$ $f_{y T}$ is the yield stress at elevated Temperature $T$

$A_{e T}$ is the effective area at yield stress $\left(f_{y T}\right)$ at elevated temperature $T$

$A_{e T}=\sum b_{e i T} t_{i}$ where $b_{e i T}$ is the effective width of element $i$ at elevated temperature $T$ and $t_{i}$ is the thickness of element $i$.

\section{AISI and AS/NZS 4600}

$b_{e T}=b$ for $\lambda_{T} \leq 0.673$

$b_{e T}=\rho_{T} b$ for $\lambda_{T}>0.673$

where

$b$ is the flat width of element excluding radii and $\rho_{T}$ is the effective width factor at elevated temperature $T$

$\rho_{T}=\frac{\left(1-\frac{0.22}{\lambda_{T}}\right)}{\lambda_{T}} \leq 1$

The slenderness ratio $\lambda_{T}$ at elevated temperature $T$ shall be determined as follows

$$
\lambda_{T}=\left[\sqrt{\frac{f_{y T}}{f_{c r T}}}\right]
$$


where

$$
f_{c r T}=\left[\frac{k \pi^{2} E_{T}}{12\left(1-v^{2}\right)}\right]\left(\frac{t}{b}\right)^{2}
$$

$k$ is the plate buckling coefficient defined in AS/NZS 4600

$E_{T}$ is the Young's modulus of elasticity at Temperature $T$

$v$ is the Poisson's ratio

$t$ is the thickness of the uniformly compressed stiffened element

\section{BS 5950 Part 5}

$b_{e T}=b$ for $f_{y T} / p_{c r T} \leq 0.123$

$$
b_{e T}=b\left[1+14\left\{\left(f_{y T} / p_{c r T}\right)^{1 / 2}-0.35\right\}^{4}\right]^{0.2} \text { for } f_{y T} / p_{c r T}>0.123
$$

where

$p_{c r T}$ is the local buckling stress of the element at elevated temperature $T$ given by

$$
p_{c r T}=0.904 E_{T} K\left(\frac{t}{b}\right)^{2}
$$

where $K$ is the local buckling coefficient which depends on element type and section geometry defined in Annex B of BS5950 Part 5.

\section{Eurocode 3 Part 1.2}

$N_{s T}=A_{e, A m b i e n t} f_{y T}$

where

$N_{s T}$ is the nominal section capacity of the member in compression at elevated temperature $T$ $A_{e, A m b i e n t}$ is the effective area at yield stress $\left(f_{y}\right)$ calculated based on Eurocode 3 Part 1.3 using ambient temperature properties.

\section{Direct Strength Method}

$$
\begin{aligned}
& P_{n l T}=P_{y T} \text { for } \lambda_{l T} \leq 0.776 \\
& P_{n l T}=P_{y T}\left(1-0.15\left(\frac{P_{c r l T}}{P_{y T}}\right)^{0.4}\right)\left(\frac{P_{c r l T}}{P_{y T}}\right)^{0.4} \text { for } \lambda_{l T}>0.776
\end{aligned}
$$


where $\lambda_{l T}=\sqrt{\frac{P_{y T}}{P_{c r l T}}}$

$P_{c r l T}$ is the critical elastic local buckling load at elevated temperature $T$ obtained from finite element modelling

$P_{n l T}$ is the column axial strengths for local buckling mode at elevated temperature $T$ $P_{y T}=A_{g} f_{y T}$ 
Table Captions

Table 1: Nominal Dimensions of Test Specimens

Table 2: Base Metal Thickness of Selected Cold-formed Steels

Table 3: Measured Dimensions and Ultimate Loads of Types A and B Specimens Tested at Ambient Temperature

Table 4: Measured Dimensions and Ultimate Loads of Type A Specimens Tested at Elevated Temperatures

Table 5: Measured Dimensions and Ultimate Loads of Type B Specimens Tested at Elevated Temperatures

Table 6: Comparison of Ultimate Loads Using the Two Loading Set-ups

Table 7: Mechanical Properties of Selected Cold-formed Steels

Table 8: Finite Element Analysis Results for Type A Specimens

Table 9: Finite Element Analysis Results for Type B Specimens

Table 10: Comparison of Ultimate Loads from Tests, FEA and Design Standards for Type A Sections

Table 11: Comparison of Ultimate Loads from Tests, FEA and Design Standards for Type B Sections 
Table 1: Nominal Dimensions of Test Specimens

\begin{tabular}{|c|c|c|c|c|c|c|c|}
\hline $\begin{array}{c}\text { Nominal } \\
\text { Thickness } \\
(\mathrm{mm})\end{array}$ & $\begin{array}{l}\text { Steel } \\
\text { Grade }\end{array}$ & $\begin{array}{c}\text { Section } \\
\text { Type }\end{array}$ & $\begin{array}{l}\text { Web } \\
\text { depth } \\
(\mathrm{mm})\end{array}$ & $\begin{array}{l}\text { Flange } \\
\text { width } \\
(\mathrm{mm}) \\
\end{array}$ & $\begin{array}{l}\text { Lip } \\
\text { Height } \\
(\mathrm{mm}) \\
\end{array}$ & $\begin{array}{l}\text { HWL } \\
(\mathrm{mm})\end{array}$ & $\begin{array}{l}\text { Specimen } \\
\text { Length } \\
(\mathrm{mm})\end{array}$ \\
\hline \multirow{4}{*}{0.95} & \multirow{2}{*}{250} & A & 60 & 30 & 9 & 50 & 190 \\
\hline & & $\mathrm{B}$ & 25 & 25 & - & 55 & 150 \\
\hline & \multirow{2}{*}{550} & $\mathrm{~A}$ & 60 & 25 & 9 & 50 & 190 \\
\hline & & B & 25 & 25 & - & 55 & 150 \\
\hline \multirow{2}{*}{1.95} & \multirow{2}{*}{250} & $\mathrm{~A}$ & 118 & 38 & 15 & 90 & 320 \\
\hline & & $\mathrm{B}$ & 48 & 49 & - & 110 & 260 \\
\hline \multirow{2}{*}{1.90} & \multirow{2}{*}{450} & A & 98 & 38 & 15 & 80 & 280 \\
\hline & & $\mathrm{B}$ & 48 & 49 & - & 110 & 260 \\
\hline
\end{tabular}

HWL: Half Wave Length

Table 2: Base Metal Thickness of Selected Cold-formed Steels

\begin{tabular}{|c|c|}
\hline $\begin{array}{c}\text { Steel grade and } \\
\text { nominal thickness }\end{array}$ & $\begin{array}{c}\text { Average base metal } \\
\text { thickness }(\mathrm{mm})\end{array}$ \\
\hline $\mathrm{G} 550-0.95$ & 0.95 \\
\hline $\mathrm{G} 250-0.95$ & 0.95 \\
\hline $\mathrm{G} 450-1.90$ & 1.88 \\
\hline $\mathrm{G} 250-1.95$ & 1.95 \\
\hline
\end{tabular}

Table 3: Measured Dimensions and Ultimate Loads of Types A and B Specimens Tested at Ambient Temperature

\begin{tabular}{|c|c|c|c|c|c|}
\hline Specimen & $\begin{array}{c}\text { Web } \\
(\mathrm{mm})\end{array}$ & $\begin{array}{c}\text { Flange } \\
(\mathrm{mm})\end{array}$ & $\begin{array}{c}\text { Lip } \\
(\mathrm{mm})\end{array}$ & $\begin{array}{c}\text { Length } \\
(\mathrm{mm})\end{array}$ & $\begin{array}{c}\text { Ult. load } \\
(\mathrm{kN})\end{array}$ \\
\hline $\mathrm{G} 550-0.95-20-\mathrm{A}^{\#}$ & 62.95 & 27.65 & 9.62 & 190 & 53.95 \\
\hline $\mathrm{G} 250-0.95-20-\mathrm{A}^{\#}$ & 63.02 & 32.53 & 9.43 & 190 & 37.09 \\
\hline $\mathrm{G} 450-1.90-20-\mathrm{A}^{\#}$ & 99.97 & 40.22 & 15.08 & 280 & 151.30 \\
\hline $\mathrm{G} 250-1.95-20-\mathrm{A}^{\#}$ & 120.43 & 40.25 & 15.98 & 320 & 102.04 \\
\hline $\mathrm{G} 550-0.95-20-\mathrm{B}^{\#}$ & 25.02 & 25.00 & - & 150 & 26.50 \\
\hline $\mathrm{G} 250-0.95-20-\mathrm{B}^{\#}$ & 25.00 & 24.95 & - & 150 & 16.83 \\
\hline $\mathrm{G} 450-1.90-20-\mathrm{B}^{\#}$ & 50.23 & 49.98 & - & 260 & 96.89 \\
\hline $\mathrm{G} 250-1.95-20-\mathrm{B}^{\#}$ & 50.30 & 50.05 & - & 260 & 66.37 \\
\hline
\end{tabular}

\# Three specimens in each case 
Table 4: Measured Dimensions and Ultimate Loads of Type A Specimens Tested at Elevated Temperatures

\begin{tabular}{|l|c|c|c|c|c|}
\hline \multicolumn{1}{|c|}{ Specimen } & $\begin{array}{c}\text { Web } \\
(\mathrm{mm})\end{array}$ & $\begin{array}{c}\text { Flange } \\
(\mathrm{mm})\end{array}$ & $\begin{array}{c}\text { Lip } \\
(\mathrm{mm})\end{array}$ & $\begin{array}{c}\text { Length } \\
(\mathrm{mm})\end{array}$ & $\begin{array}{c}\text { Ult. Load } \\
(\mathrm{kN})\end{array}$ \\
\hline G550-0.95-100-A & 62.85 & 27.65 & 9.60 & 190.0 & 53.47 \\
\hline G550-0.95-200-A & 63.40 & 27.75 & 9.65 & 190.0 & 52.12 \\
\hline G550-0.95-300-A & 63.27 & 27.70 & 9.60 & 190.0 & 47.83 \\
\hline G550-0.95-400-A & 63.32 & 27.61 & 9.67 & 190.0 & 36.43 \\
\hline G550-0.95-500-A & 63.50 & 27.75 & 9.65 & 190.0 & 21.36 \\
\hline G550-0.95-600-A & 63.07 & 27.72 & 9.67 & 190.0 & 6.55 \\
\hline G550-0.95-700-A & 63.55 & 27.55 & 9.65 & 190.0 & 4.00 \\
\hline G250-0.95-200-A & 63.75 & 32.75 & 9.50 & 189.2 & 36.59 \\
\hline G250-0.95-300-A & 63.52 & 33.47 & 9.77 & 189.3 & 30.39 \\
\hline G250-0.95-400-A & 64.35 & 33.00 & 9.75 & 189.7 & 23.95 \\
\hline G250-0.95-500-A & 63.80 & 33.55 & 9.82 & 189.0 & 15.11 \\
\hline G250-0.95-600-A & 63.55 & 33.50 & 9.70 & 190.0 & 9.30 \\
\hline G250-0.95-700-A & 63.80 & 33.50 & 9.80 & 189.0 & 5.45 \\
\hline G450-1.90-300-A & 99.70 & 40.05 & 15.10 & 280.0 & 146.18 \\
\hline G450-1.90-500-A & 99.93 & 40.07 & 15.07 & 280.0 & 70.10 \\
\hline G450-1.90-600-A & 99.60 & 40.20 & 15.00 & 280.0 & 23.65 \\
\hline G450-1.90-700-A & 100.10 & 40.05 & 15.10 & 280.0 & 11.64 \\
\hline G250-1.95-300-A & 120.50 & 40.15 & 15.15 & 320.0 & 80.92 \\
\hline G250-1.95-400-A & 120.50 & 40.15 & 15.15 & 320.0 & 61.60 \\
\hline G250-1.95-500-A & 120.70 & 40.20 & 15.00 & 320.0 & 37.58 \\
\hline G250-1.95-600-A & 120.05 & 40.10 & 15.05 & 320.0 & 23.00 \\
\hline G250-1.95-700-A & 120.60 & 40.35 & 15.05 & 320.0 & 14.86 \\
\hline
\end{tabular}

* Two Specimens in each case

\# Three Specimens in each case 
Table 5: Measured Dimensions and Ultimate Loads of Type B Specimens Tested at Elevated Temperatures

\begin{tabular}{|c|c|c|c|c|}
\hline Specimen & $\begin{array}{c}\text { Web } \\
(\mathrm{mm})\end{array}$ & $\begin{array}{c}\text { Flange } \\
(\mathrm{mm})\end{array}$ & $\begin{array}{c}\text { Length } \\
(\mathrm{mm})\end{array}$ & $\begin{array}{c}\text { Ult. Load } \\
(\mathrm{kN})\end{array}$ \\
\hline G550-0.95-200-B & 25.05 & 25.00 & 150 & 26.36 \\
\hline G550-0.95-300-B & 24.97 & 24.92 & 150 & 25.91 \\
\hline G550-0.95-400-B & 25.02 & 25.00 & 150 & 22.08 \\
\hline G550-0.95-500-B & 24.90 & 25.00 & 150 & 14.32 \\
\hline G550-0.95-600-B & 25.00 & 25.00 & 150 & 4.15 \\
\hline G550-0.95-700-B & 25.00 & 25.05 & 150 & 2.02 \\
\hline G250-0.95-200-B & 25.07 & 24.95 & 150 & 16.07 \\
\hline G250-0.95-300-B & 25.00 & 25.12 & 150 & 10.70 \\
\hline G250-0.95-400-B & 25.00 & 24.95 & 150 & 9.25 \\
\hline G250-0.95-500-B & 24.85 & 24.90 & 150 & 7.85 \\
\hline G250-0.95-600-B & 25.05 & 25.05 & 150 & 3.64 \\
\hline G250-0.95-700-B & 25.00 & 25.10 & 150 & 2.22 \\
\hline G450-1.90-200-B & 50.15 & 49.70 & 260 & 86.39 \\
\hline G450-1.90-300-B & 50.05 & 50.05 & 260 & 86.10 \\
\hline G450-1.90-400-B & 51.02 & 50.00 & 260 & 58.49 \\
\hline G450-1.90-500-B & 50.17 & 49.97 & 260 & 35.75 \\
\hline G450-1.90-600-B & 50.15 & 49.95 & 260 & 14.00 \\
\hline G450-1.90-700-B & 50.00 & 50.00 & 260 & 8.06 \\
\hline G250-1.95-200-B & 50.10 & 50.00 & 260 & 69.60 \\
\hline G250-1.95-300-B & 50.50 & 50.00 & 260 & 42.74 \\
\hline G250-1.95-400-B & 50.17 & 50.02 & 260 & 36.53 \\
\hline G250-1.95-500-B & 50.15 & 50.00 & 260 & 22.69 \\
\hline G250-1.95-600-B & 50.00 & 50.15 & 260 & 15.10 \\
\hline G250-1.95-700-B & 50.15 & 50.10 & 260 & 9.24 \\
\hline
\end{tabular}

* Two Specimens in each case

\# Three Specimens in each case

Table 6: Comparison of Ultimate Loads Using the Two Loading Set-ups

\begin{tabular}{|c|c|c|c|c|c|}
\hline \multirow{2}{*}{$\begin{array}{c}\text { Specimen } \\
\end{array}$} & \multicolumn{3}{|c|}{$\begin{array}{c}\text { Without loading shaft } \\
\text { arrangement }(\mathrm{kN})\end{array}$} & \multicolumn{2}{c|}{$\begin{array}{c}\text { With loading shaft } \\
\text { arrangement inside the } \\
\text { furnace }(\mathrm{kN})\end{array}$} \\
\cline { 2 - 6 } & P1 & P2 & P3 & P1 & P2 \\
\hline G450-1.9-20-A & 150.67 & 153.23 & 149.99 & 148.57 & 149.22 \\
\hline G250-1.9-20-A & 105.55 & 100.88 & 99.71 & 100.30 & 101.57 \\
\hline
\end{tabular}


Table 7: Mechanical Properties of Selected Cold-formed Steels

\begin{tabular}{|c|c|c|c|}
\hline Steel & $\begin{array}{c}\text { Temperature } \\
\left({ }^{\circ} \mathrm{C}\right)\end{array}$ & $E(\mathrm{MPa})$ & $f_{y}(\mathrm{MPa})$ \\
\hline \multirow{7}{*}{ G550-0.95 } & 20 & 205000 & 615 \\
\hline & 200 & 174189 & 609 \\
\hline & 300 & 146596 & 584 \\
\hline & 400 & 118921 & 427 \\
\hline & 500 & 91246 & 240 \\
\hline & 600 & 63571 & 67.7 \\
\hline & 700 & 35896 & 43.1 \\
\hline \multirow{7}{*}{ G250-0.95 } & 20 & 200000 & 320 \\
\hline & 200 & 169940 & 291 \\
\hline & 300 & 143020 & 210 \\
\hline & 400 & 116020 & 153 \\
\hline & 500 & 89020 & 108 \\
\hline & 600 & 62020 & 71.1 \\
\hline & 700 & 35020 & 39.8 \\
\hline \multirow{7}{*}{ G450-1.90 } & 20 & 206000 & 515 \\
\hline & 200 & 173337 & 510 \\
\hline & 300 & 148395 & 484 \\
\hline & 400 & 118533 & 362 \\
\hline & 500 & 77100 & 197 \\
\hline & 600 & 52536 & 56.4 \\
\hline & 700 & 24286 & 34.2 \\
\hline \multirow{7}{*}{ G250-1.95 } & 20 & 188000 & 271 \\
\hline & 200 & 171745 & 257 \\
\hline & 300 & 154330 & 196 \\
\hline & 400 & 121230 & 148 \\
\hline & 500 & 90631 & 96 \\
\hline & 600 & 57777 & 54.0 \\
\hline & 700 & 31363 & 34.2 \\
\hline
\end{tabular}


Table 8: Finite Element Analysis Results for Type A Specimens

\begin{tabular}{|c|c|c|c|c|c|}
\hline \multirow{2}{*}{$\begin{array}{l}\text { Specimen } \\
\text { Type }\end{array}$} & \multirow{2}{*}{$\begin{array}{l}\text { Temp } \\
\left({ }^{\circ} \mathrm{C}\right)\end{array}$} & \multirow{2}{*}{$\begin{array}{l}\text { Test Ult. } \\
\text { Load }(\mathrm{kN})\end{array}$} & \multicolumn{2}{|c|}{ FEA Results (kN) } & \multirow{2}{*}{$\begin{array}{l}\text { Test/FEA } \\
\text { Ult. Load }\end{array}$} \\
\hline & & & EBL & $\begin{array}{l}\text { Ult. } \\
\text { Load }\end{array}$ & \\
\hline \multirow{10}{*}{$\begin{array}{l}\text { G550- } \\
0.95-A\end{array}$} & 20 & 53.95 & 32.43 & 55.00 & 0.98 \\
\hline & 100 & 53.47 & 30.32 & 54.40 & 0.98 \\
\hline & 200 & 52.12 & 27.37 & 52.70 & 0.99 \\
\hline & 300 & 47.83 & 23.06 & 48.40 & 0.99 \\
\hline & 400 & 36.43 & 18.69 & 35.70 & 1.02 \\
\hline & 500 & 21.36 & 14.30 & 21.80 & 0.98 \\
\hline & 600 & 6.55 & 10.05 & 7.01 & 0.93 \\
\hline & 700 & 4.00 & 5.61 & 4.38 & 0.91 \\
\hline & \multicolumn{4}{|c|}{ Mean } & 0.97 \\
\hline & \multicolumn{4}{|c|}{$\mathrm{COV}$} & 0.03 \\
\hline \multirow{7}{*}{$\begin{array}{l}\text { G450- } \\
1.90-A\end{array}$} & 20 & 151.30 & 152.64 & 162.00 & 0.93 \\
\hline & 300 & 146.18 & 110.42 & 141.00 & 1.04 \\
\hline & 500 & 70.10 & 57.17 & 59.90 & 1.17 \\
\hline & 600 & 23.65 & 39.15 & 19.80 & 1.19 \\
\hline & 700 & 11.64 & 17.97 & 11.50 & 1.01 \\
\hline & \multicolumn{4}{|c|}{ Mean } & 1.07 \\
\hline & \multicolumn{4}{|c|}{$\mathrm{COV}$} & 0.10 \\
\hline \multirow{8}{*}{$\begin{array}{l}\text { G250- } \\
1.95-A\end{array}$} & 20 & 102.04 & 120.42 & 105.00 & 0.97 \\
\hline & 300 & 82.92 & 97.81 & 72.30 & 1.15 \\
\hline & 400 & 61.60 & 76.83 & 53.60 & 1.15 \\
\hline & 500 & 37.58 & 57.24 & 34.90 & 1.08 \\
\hline & 600 & 23.00 & 36.75 & 20.50 & 1.12 \\
\hline & 700 & 14.86 & 19.86 & 12.90 & 1.15 \\
\hline & \multicolumn{4}{|c|}{ Mean } & 1.10 \\
\hline & \multicolumn{4}{|c|}{$\mathrm{COV}$} & 0.06 \\
\hline
\end{tabular}

EBL - Elastic Buckling Load 
Table 9: Finite Element Analysis Results for Type B Specimens

\begin{tabular}{|c|c|c|c|c|c|}
\hline \multirow{2}{*}{$\begin{array}{l}\text { Specimen } \\
\text { Type }\end{array}$} & \multirow{2}{*}{$\begin{array}{l}\text { Temp. } \\
\left({ }^{\circ} \mathrm{C}\right)\end{array}$} & \multirow{2}{*}{$\begin{array}{l}\text { Test Ult. } \\
\text { Load }(\mathrm{kN})\end{array}$} & \multicolumn{2}{|c|}{ FEA Results (kN) } & \multirow{2}{*}{$\begin{array}{l}\text { Test/FEA } \\
\text { Ult. Load }\end{array}$} \\
\hline & & & EBL & Ult. Load & \\
\hline \multirow{9}{*}{$\begin{array}{c}\text { G550-0.95- } \\
\text { B }\end{array}$} & 20 & 26.50 & 19.01 & 29.00 & 0.91 \\
\hline & 200 & 26.36 & 16.16 & 27.30 & 0.97 \\
\hline & 300 & 25.91 & 13.64 & 25.00 & 1.04 \\
\hline & 400 & 22.08 & 11.03 & 18.70 & 1.18 \\
\hline & 500 & 14.32 & 8.46 & 11.30 & 1.27 \\
\hline & 600 & 4.15 & 5.90 & 3.94 & 1.05 \\
\hline & 700 & 2.02 & 3.32 & 2.44 & 0.83 \\
\hline & \multicolumn{4}{|c|}{ Mean } & 1.03 \\
\hline & \multicolumn{4}{|c|}{$\mathrm{COV}$} & 0.15 \\
\hline \multirow{9}{*}{$\begin{array}{c}\text { G250-0.95- } \\
\text { B }\end{array}$} & 20 & 16.83 & 18.59 & 17.80 & 0.95 \\
\hline & 200 & 16.07 & 15.80 & 15.90 & 1.01 \\
\hline & 300 & 10.70 & 13.18 & 11.00 & 0.97 \\
\hline & 400 & 9.25 & 10.78 & 8.01 & 1.15 \\
\hline & 500 & 7.85 & 8.29 & 5.69 & 1.38 \\
\hline & 600 & 3.64 & 5.74 & 3.96 & 0.92 \\
\hline & 700 & 2.22 & 3.23 & 2.28 & 0.97 \\
\hline & \multicolumn{4}{|c|}{ Mean } & 1.05 \\
\hline & \multicolumn{4}{|c|}{$\mathrm{COV}$} & 0.16 \\
\hline \multirow{9}{*}{$\begin{array}{c}\text { G450-1.90- } \\
\text { B }\end{array}$} & 20 & 96.89 & 74.62 & 101.00 & 0.96 \\
\hline & 200 & 86.39 & 63.04 & 99.70 & 0.87 \\
\hline & 300 & 86.10 & 53.56 & 87.20 & 0.99 \\
\hline & 400 & 58.49 & 42.82 & 66.10 & 0.88 \\
\hline & 500 & 35.75 & 27.88 & 37.50 & 0.95 \\
\hline & 600 & 14.00 & 19.01 & 13.00 & 1.08 \\
\hline & 700 & 8.06 & 8.77 & 7.38 & 1.09 \\
\hline & \multicolumn{4}{|c|}{ Mean } & 0.97 \\
\hline & \multicolumn{4}{|c|}{$\mathrm{COV}$} & 0.09 \\
\hline \multirow{9}{*}{$\begin{array}{c}\text { G250-1.95- } \\
\text { B }\end{array}$} & 20 & 66.37 & 75.87 & 65.50 & 1.01 \\
\hline & 200 & 69.60 & 69.25 & 61.50 & 1.13 \\
\hline & 300 & 42.74 & 62.32 & 44.80 & 0.95 \\
\hline & 400 & 36.53 & 48.87 & 33.20 & 1.10 \\
\hline & 500 & 22.69 & 36.55 & 21.90 & 1.04 \\
\hline & 600 & 15.10 & 23.22 & 13.00 & 1.16 \\
\hline & 700 & 9.24 & 12.62 & 8.19 & 1.13 \\
\hline & \multicolumn{4}{|c|}{ Mean } & 1.08 \\
\hline & \multicolumn{4}{|c|}{$\mathrm{COV}$} & 0.07 \\
\hline
\end{tabular}

EBL - Elastic Buckling Load 
Table 10: Comparison of Ultimate Loads from Tests, FEA and Design Standards for Type A Sections

\begin{tabular}{|c|c|c|c|c|c|c|c|c|c|c|c|c|c|}
\hline \multirow[b]{2}{*}{ Specimen } & \multirow[b]{2}{*}{$\begin{array}{c}\text { Temp. } \\
\left({ }^{\circ} \mathrm{C}\right)\end{array}$} & \multicolumn{7}{|c|}{ Ultimate Load $(\mathrm{kN})$} & \multicolumn{5}{|c|}{ FEA/Predicted } \\
\hline & & Test & FEA & $\begin{array}{l}\text { AS / } \\
\text { NZS } \\
4600\end{array}$ & $\begin{array}{l}\text { EC3 } \\
\text { P1.2 }\end{array}$ & $\begin{array}{l}\text { EC3 } \\
\text { P1.3 }\end{array}$ & $\begin{array}{c}\text { BS } \\
5950 \\
\text { P5 }\end{array}$ & DSM & $\begin{array}{l}\text { AS / } \\
\text { NZS } \\
4600\end{array}$ & $\begin{array}{l}\text { EC3 } \\
\text { P1.2 }\end{array}$ & $\begin{array}{l}\text { EC3 } \\
\text { P1.3 }\end{array}$ & $\begin{array}{c}\text { BS } \\
5950 \\
\text { P5 }\end{array}$ & DSM \\
\hline \multirow{11}{*}{$\begin{array}{c}\text { G550 } \\
0.95 \\
\text { A }\end{array}$} & 20 & 53.95 & 55.00 & 47.17 & 48.50 & 48.50 & 52.90 & 49.14 & 1.17 & 1.13 & 1.13 & 1.04 & 1.12 \\
\hline & 100 & 53.47 & 54.40 & 45.61 & 48.45 & 46.91 & 51.61 & 47.95 & 1.19 & 1.12 & 1.16 & 1.05 & 1.13 \\
\hline & 200 & 52.12 & 52.70 & 43.67 & 48.08 & 44.60 & 49.59 & 46.16 & 1.21 & 1.10 & 1.18 & 1.06 & 1.14 \\
\hline & 300 & 47.83 & 48.40 & 39.28 & 46.07 & 39.81 & 45.07 & 42.20 & 1.23 & 1.05 & 1.22 & 1.07 & 1.15 \\
\hline & 400 & 36.43 & 35.70 & 30.22 & 33.75 & 30.88 & 34.37 & 32.00 & 1.18 & 1.06 & 1.16 & 1.04 & 1.12 \\
\hline & 500 & 21.36 & 21.80 & 19.58 & 18.96 & 20.10 & 21.58 & 20.12 & 1.11 & 1.15 & 1.08 & 1.01 & 1.08 \\
\hline & 600 & 6.55 & 7.01 & 7.48 & 5.35 & 7.46 & 7.41 & 7.70 & 0.94 & 1.31 & 0.94 & 0.95 & 0.91 \\
\hline & 700 & 4.00 & 4.38 & 4.67 & 3.40 & 4.60 & 4.60 & 4.70 & 0.94 & 1.29 & 0.95 & 0.95 & 0.93 \\
\hline & \multicolumn{8}{|c|}{ Mean } & 1.121 & 1.151 & 1.103 & 1.022 & 1.073 \\
\hline & \multicolumn{8}{|c|}{$\mathrm{COV}$} & 0.106 & 0.085 & 0.094 & 0.048 & 0.089 \\
\hline & \multicolumn{8}{|c|}{$\varphi$} & 0.949 & 1.003 & 0.949 & 0.926 & 0.930 \\
\hline \multirow{8}{*}{$\begin{array}{c}\text { G450 } \\
1.90 \\
\text { A }\end{array}$} & 20 & 151.3 & 162.0 & 155.8 & 150.1 & 150.1 & 155.2 & 153.4 & 1.04 & 1.08 & 1.08 & 1.04 & 1.06 \\
\hline & 300 & 146.1 & 141.0 & 126.3 & 140.9 & 130.0 & 138.1 & 131.7 & 1.12 & 1.00 & 1.08 & 1.02 & 1.07 \\
\hline & 500 & 70.10 & 59.90 & 59.04 & 57.37 & 57.03 & 59.09 & 58.27 & 1.01 & 1.04 & 1.05 & 1.01 & 1.03 \\
\hline & 600 & 23.65 & 19.80 & 19.85 & 16.42 & 19.83 & 19.93 & 21.47 & 1.00 & 1.21 & 1.00 & 0.99 & 0.92 \\
\hline & 700 & 11.64 & 11.50 & 11.56 & 9.96 & 11.55 & 11.51 & 12.30 & 0.99 & 1.15 & 1.00 & 1.00 & 0.93 \\
\hline & \multicolumn{8}{|c|}{ Mean } & 1.032 & 1.097 & 1.041 & 1.014 & 1.002 \\
\hline & \multicolumn{8}{|c|}{$\mathrm{COV}$} & 0.048 & 0.076 & 0.041 & 0.019 & 0.069 \\
\hline & \multicolumn{8}{|c|}{$\varphi$} & 0.925 & 0.945 & 0.941 & 0.931 & 0.873 \\
\hline \multirow{9}{*}{$\begin{array}{c}\mathrm{G} 250 \\
1.95 \\
\mathrm{~A}\end{array}$} & 20 & 102.0 & 105.0 & 98.42 & 98.59 & 98.59 & 96.71 & 101.3 & 1.07 & 1.07 & 1.07 & 1.09 & 1.04 \\
\hline & 300 & 80.92 & 72.30 & 72.26 & 70.54 & 72.24 & 71.37 & 75.96 & 1.00 & 1.02 & 1.00 & 1.01 & 0.95 \\
\hline & 400 & 61.60 & 53.60 & 54.72 & 53.04 & 54.73 & 54.18 & 57.93 & 0.98 & 1.01 & 0.98 & 0.99 & 0.93 \\
\hline & 500 & 37.58 & 34.90 & 36.32 & 34.36 & 36.33 & 36.18 & 39.29 & 0.96 & 1.02 & 0.96 & 0.96 & 0.89 \\
\hline & 600 & 23.00 & 20.50 & 20.89 & 19.36 & 20.88 & 20.90 & 23.01 & 0.98 & 1.06 & 0.98 & 0.98 & 0.89 \\
\hline & 700 & 14.86 & 12.90 & 12.94 & 12.28 & 12.93 & 12.86 & 13.91 & 1.00 & 1.05 & 1.00 & 1.00 & 0.93 \\
\hline & \multicolumn{8}{|c|}{ Mean } & 0.998 & 1.038 & 0.998 & 1.006 & 0.937 \\
\hline & \multicolumn{8}{|c|}{$\mathrm{COV}$} & 0.037 & 0.023 & 0.036 & 0.042 & 0.058 \\
\hline & \multicolumn{8}{|c|}{$\varphi$} & 0.908 & 0.952 & 0.908 & 0.911 & 0.836 \\
\hline
\end{tabular}


Table 11: Comparison of Ultimate Loads from Tests, FEA and Design Standards for Type B Sections

\begin{tabular}{|c|c|c|c|c|c|c|c|c|c|c|c|c|c|}
\hline \multirow[b]{2}{*}{ Specimen } & \multirow[b]{2}{*}{$\begin{array}{l}\text { Temp. } \\
\left({ }^{\circ} \mathrm{C}\right)\end{array}$} & \multicolumn{7}{|c|}{ Ultimate Load (kN) } & \multicolumn{5}{|c|}{ FEA/Predicted } \\
\hline & & Test & FEA & $\begin{array}{l}\text { AS / } \\
\text { NZS } \\
4600\end{array}$ & $\begin{array}{l}\text { EC3 } \\
\text { P1.2 }\end{array}$ & $\begin{array}{l}\text { EC3 } \\
\text { P1.3 }\end{array}$ & $\begin{array}{c}\text { BS } \\
5950 \\
\text { P5 }\end{array}$ & DSM & $\begin{array}{l}\text { AS / } \\
\text { NZS } \\
4600\end{array}$ & $\begin{array}{l}\text { EC3 } \\
\text { P1.2 }\end{array}$ & $\begin{array}{l}\text { EC3 } \\
\text { P1.3 }\end{array}$ & $\begin{array}{c}\text { BS } \\
5950 \\
\text { P5 }\end{array}$ & DSM \\
\hline \multirow{10}{*}{$\begin{array}{c}\text { G550 } \\
0.95 \\
\text { B }\end{array}$} & 20 & 26.50 & 29.00 & 25.07 & 25.04 & 25.04 & 23.33 & 27.54 & 1.16 & 1.16 & 1.16 & 1.24 & 1.05 \\
\hline & 200 & 26.36 & 27.30 & 23.47 & 24.80 & 23.45 & 22.02 & 25.86 & 1.16 & 1.10 & 1.16 & 1.24 & 1.06 \\
\hline & 300 & 25.91 & 25.00 & 21.41 & 23.80 & 21.38 & 20.15 & 23.65 & 1.17 & 1.05 & 1.17 & 1.24 & 1.06 \\
\hline & 400 & 22.08 & 18.70 & 16.30 & 17.37 & 16.27 & 15.29 & 17.95 & 1.15 & 1.08 & 1.15 & 1.22 & 1.04 \\
\hline & 500 & 14.32 & 11.30 & 10.26 & 9.77 & 10.24 & 9.45 & 11.25 & 1.10 & 1.16 & 1.10 & 1.20 & 1.00 \\
\hline & 600 & 4.15 & 3.94 & 3.52 & 2.75 & 3.55 & 3.37 & 4.30 & 1.12 & 1.43 & 1.11 & 1.17 & 0.92 \\
\hline & 700 & 2.02 & 2.44 & 2.19 & 1.75 & 2.20 & 2.08 & 2.63 & 1.11 & 1.39 & 1.11 & 1.18 & 0.93 \\
\hline & \multicolumn{8}{|c|}{ Mean } & 1.139 & 1.196 & 1.138 & 1.213 & 1.008 \\
\hline & \multicolumn{8}{|c|}{$\mathrm{COV}$} & 0.023 & 0.129 & 0.026 & 0.026 & 0.061 \\
\hline & \multicolumn{8}{|c|}{$\varphi$} & 1.045 & 0.964 & 1.043 & 1.112 & 0.900 \\
\hline \multirow{10}{*}{$\begin{array}{c}\text { G250 } \\
0.95 \\
\text { B }\end{array}$} & 20 & 16.83 & 17.80 & 15.23 & 15.29 & 15.29 & 14.32 & 17.78 & 1.17 & 1.16 & 1.16 & 1.24 & 1.00 \\
\hline & 200 & 16.07 & 15.90 & 13.66 & 13.93 & 13.72 & 12.82 & 15.83 & 1.16 & 1.14 & 1.16 & 1.24 & 1.00 \\
\hline & 300 & 10.70 & 12.00 & 10.25 & 10.06 & 10.25 & 9.62 & 12.03 & 1.07 & 1.09 & 1.07 & 1.14 & 0.91 \\
\hline & 400 & 9.25 & 8.01 & 7.59 & 7.30 & 7.64 & 7.19 & 9.06 & 1.06 & 1.10 & 1.05 & 1.11 & 0.88 \\
\hline & 500 & 7.85 & 5.69 & 5.46 & 5.14 & 5.48 & 5.17 & 6.56 & 1.04 & 1.11 & 1.04 & 1.10 & 0.87 \\
\hline & 600 & 3.64 & 3.96 & 3.65 & 3.40 & 3.67 & 3.47 & 4.42 & 1.08 & 1.16 & 1.08 & 1.14 & 0.90 \\
\hline & 700 & 2.22 & 2.28 & 2.05 & 1.90 & 2.06 & 1.95 & 2.48 & 1.11 & 1.20 & 1.11 & 1.17 & 0.92 \\
\hline & \multicolumn{8}{|c|}{ Mean } & 1.100 & 1.138 & 1.095 & 1.165 & 0.927 \\
\hline & \multicolumn{8}{|c|}{$\mathrm{COV}$} & 0.046 & 0.036 & 0.046 & 0.049 & 0.059 \\
\hline & \multicolumn{8}{|c|}{$\varphi$} & 0.996 & 1.038 & 0.992 & 1.052 & 0.829 \\
\hline \multirow{10}{*}{$\begin{array}{c}\text { G450 } \\
1.90 \\
\text { B }\end{array}$} & 20 & 96.89 & 101.0 & 87.75 & 88.01 & 88.01 & 81.05 & 96.89 & 1.15 & 1.15 & 1.15 & 1.25 & 1.04 \\
\hline & 200 & 86.39 & 99.70 & 82.04 & 87.11 & 82.20 & 76.63 & 90.58 & 1.22 & 1.14 & 1.21 & 1.30 & 1.10 \\
\hline & 300 & 86.10 & 87.20 & 75.14 & 82.54 & 75.07 & 70.35 & 82.86 & 1.16 & 1.06 & 1.16 & 1.24 & 1.05 \\
\hline & 400 & 58.49 & 66.10 & 57.65 & 61.86 & 57.56 & 53.76 & 63.46 & 1.15 & 1.07 & 1.15 & 1.23 & 1.04 \\
\hline & 500 & 35.75 & 37.50 & 33.34 & 33.67 & 33.40 & 30.83 & 36.77 & 1.12 & 1.11 & 1.12 & 1.22 & 1.02 \\
\hline & 600 & 14.00 & 13.00 & 11.58 & 9.63 & 11.66 & 11.04 & 14.09 & 1.12 & 1.35 & 1.11 & 1.18 & 0.92 \\
\hline & 700 & 8.06 & 7.38 & 6.61 & 5.84 & 6.63 & 6.22 & 7.81 & 1.12 & 1.26 & 1.11 & 1.19 & 0.94 \\
\hline & \multicolumn{8}{|c|}{ Mean } & 1.148 & 1.164 & 1.146 & 1.228 & 1.018 \\
\hline & \multicolumn{8}{|c|}{$\mathrm{COV}$} & 0.029 & 0.092 & 0.030 & 0.034 & 0.062 \\
\hline & \multicolumn{8}{|c|}{$\varphi$} & 1.051 & 0.999 & 1.048 & 1.121 & 0.908 \\
\hline \multirow{10}{*}{$\begin{array}{c}\mathrm{G} 250 \\
1.95 \\
\mathrm{~B}\end{array}$} & 20 & 66.37 & 65.50 & 54.80 & 55.16 & 55.16 & 51.86 & 65.28 & 1.20 & 1.19 & 1.19 & 1.26 & 1.00 \\
\hline & 200 & 69.60 & 61.50 & 51.66 & 52.35 & 51.88 & 48.72 & 61.12 & 1.19 & 1.17 & 1.19 & 1.26 & 1.01 \\
\hline & 300 & 42.74 & 49.10 & 41.97 & 40.11 & 41.28 & 38.96 & 49.38 & 1.07 & 1.12 & 1.09 & 1.15 & 0.91 \\
\hline & 400 & 36.53 & 33.20 & 31.03 & 30.07 & 31.27 & 29.54 & 37.60 & 1.07 & 1.10 & 1.06 & 1.12 & 0.88 \\
\hline & 500 & 22.69 & 21.90 & 20.78 & 19.50 & 20.97 & 19.92 & 25.52 & 1.05 & 1.12 & 1.04 & 1.10 & 0.86 \\
\hline & 600 & 15.10 & 13.00 & 12.07 & 10.97 & 12.16 & 11.60 & 14.95 & 1.08 & 1.19 & 1.07 & 1.12 & 0.87 \\
\hline & 700 & 9.24 & 8.19 & 7.39 & 6.96 & 7.43 & 7.05 & 9.02 & 1.11 & 1.18 & 1.10 & 1.16 & 0.91 \\
\hline & \multicolumn{8}{|c|}{ Mean } & 1.109 & 1.153 & 1.105 & 1.169 & 0.919 \\
\hline & \multicolumn{8}{|c|}{$\mathrm{COV}$} & 0.054 & 0.031 & 0.053 & 0.058 & 0.067 \\
\hline & \multicolumn{8}{|c|}{$\varphi$} & 0.997 & 1.054 & 0.994 & 1.047 & 0.816 \\
\hline
\end{tabular}


Figure Captions

Figure 1: Selected Cross-Sections for Local Buckling Tests

Figure 2: Buckling Plots from Finite Strip Analyses

Figure 3: Test Set-up at Ambient Temperature

Figure 4: Load-Deflection Curves for G550-0.95-20-B Section

Figure 5: Test Set-up at Elevated Temperatures

Figure 6: Local Buckling Failures at Elevated Temperatures

Figure 7: Typical Load-Deflection Curves of G550-0.95-300-BSection

Figure 8: Load-Shortening Curves of G550-0.95-20-A Section from FEA Using Different

Shell Element Types and Tests

Figure 9: Effect of Element Size on Elastic Buckling and Ultimate Loads of G550-0.95-20-A

Section

Figure 10: Finite Element Model of Lipped Channel Column

Figure 11: Stress-Strain Models

Figure 12: Load-Shortening Curves of G550-0.95-A Specimens from FEA with Different Mechanical Property Models and Tests

Figure 13: Stress-strain Curves at Elevated Temperatures

Figure 14: Comparison of Load-Shortening Curves from Tests and FEA

Figure 15: Comparison of Failure Modes from Tests and FEA

Figure 16: Comparison of Different Standards with Temperatures

Figure 17: Comparison of Ultimate Load Results with DSM Design Curve 


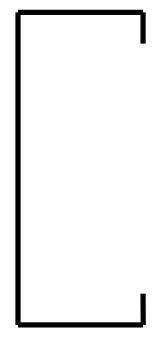

(a) Type A section

subject to local web buckling

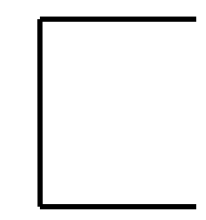

(b) Type B section

subject to local flange buckling

Figure 1: Selected Cross-Sections for Local Buckling Tests

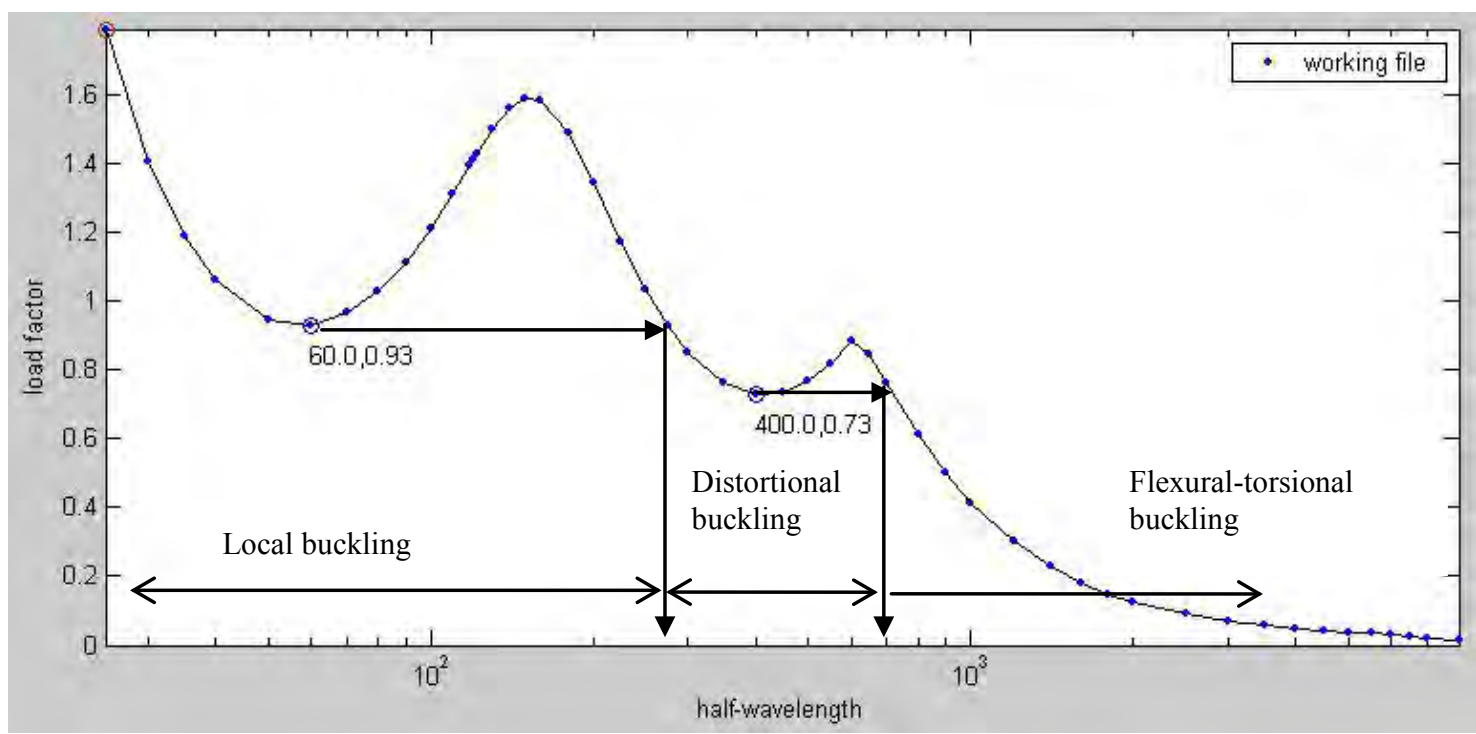

(a) Lipped channel section

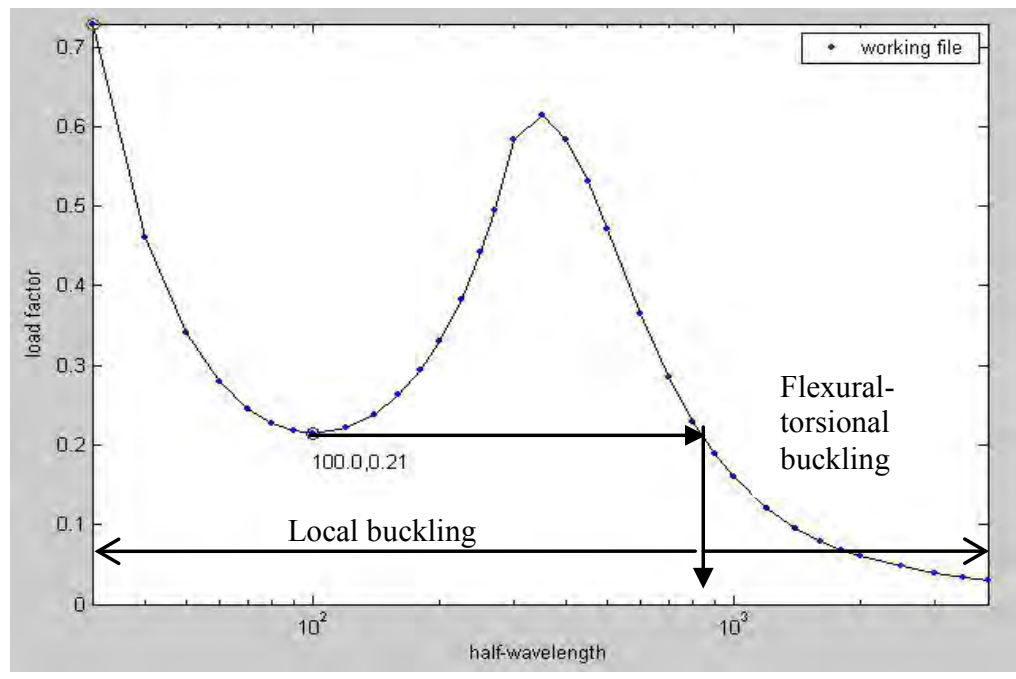

(b) Unlipped channel section 
Figure 2: Buckling Plots from Finite Strip Analyses

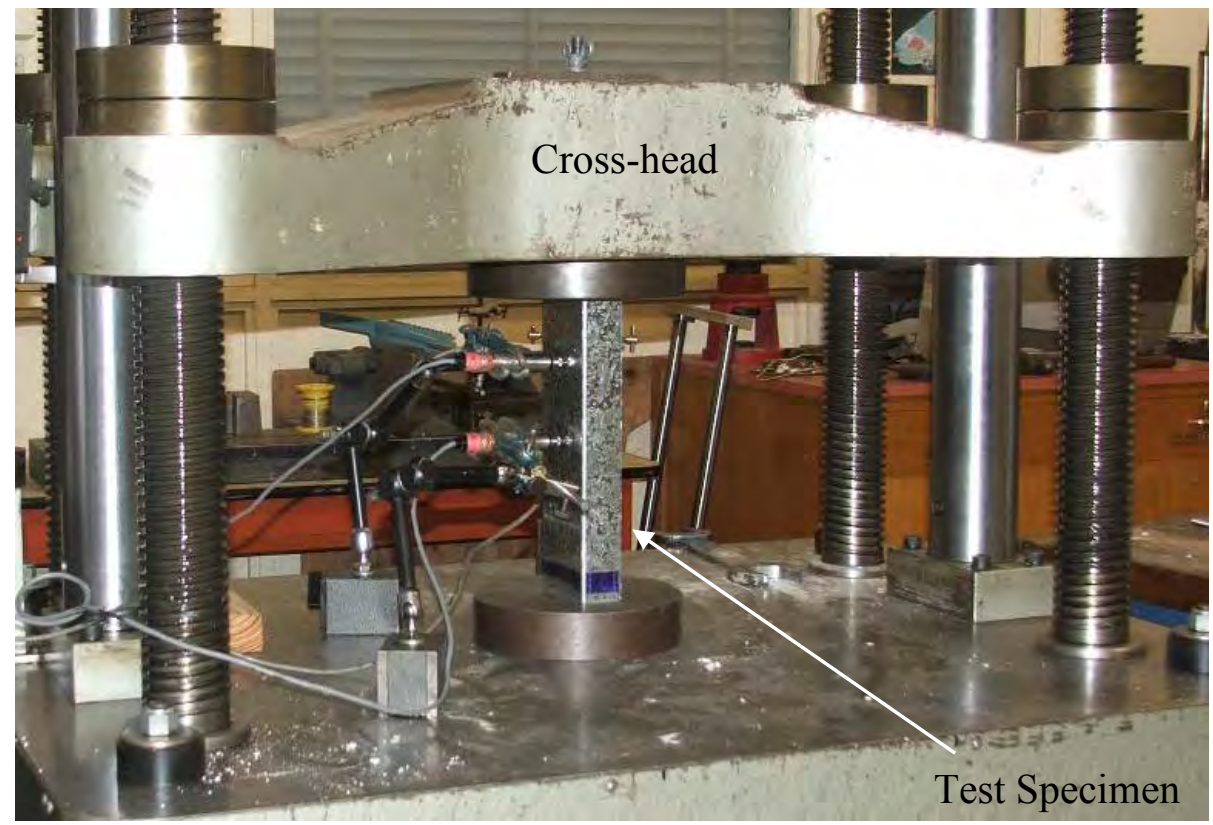

(a) Tinius Olsen testing machine

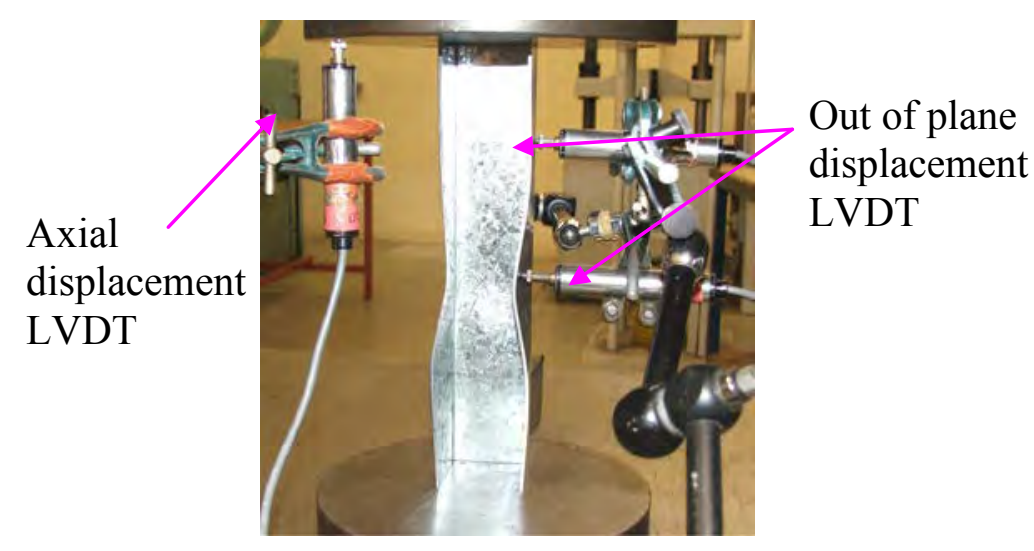

(b) Displacement measurements using LVDTs

Figure 3: Test Set-up at Ambient Temperature 


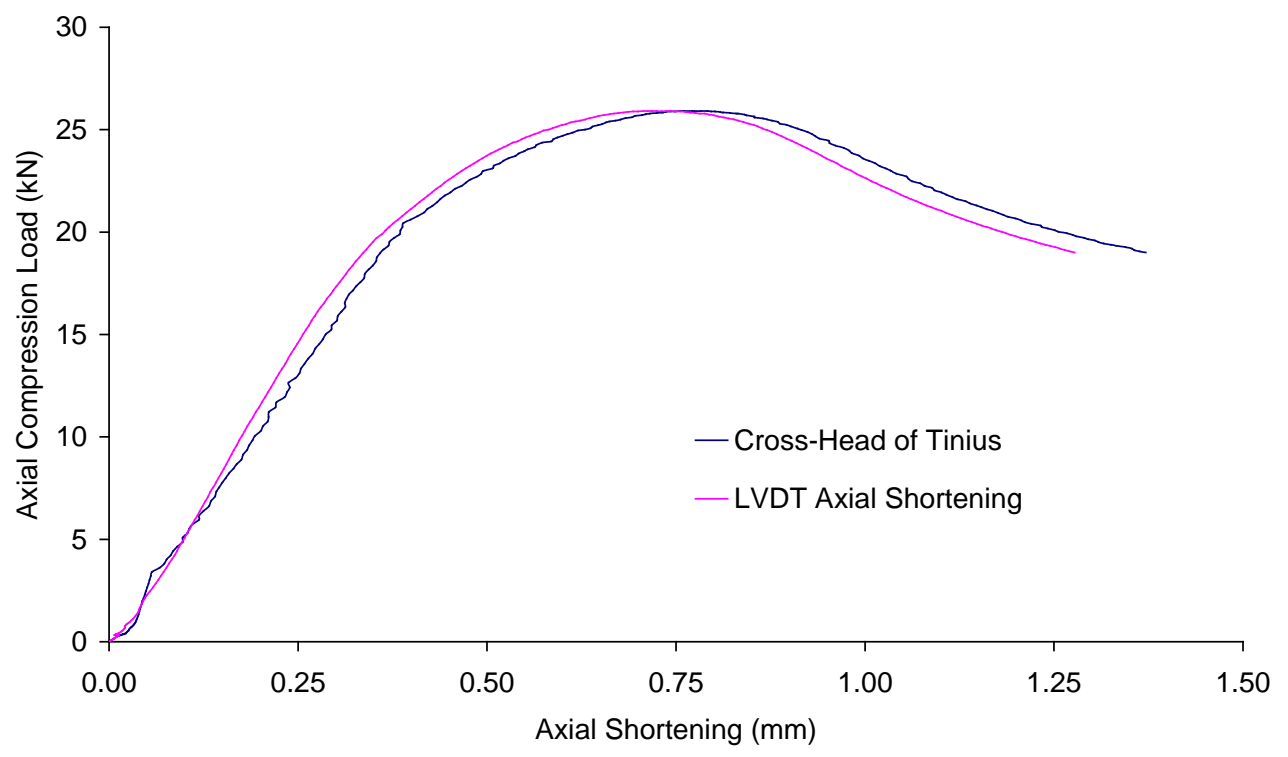

Figure 4: Load-Deflection Curves for G550-0.95-20-B Section 


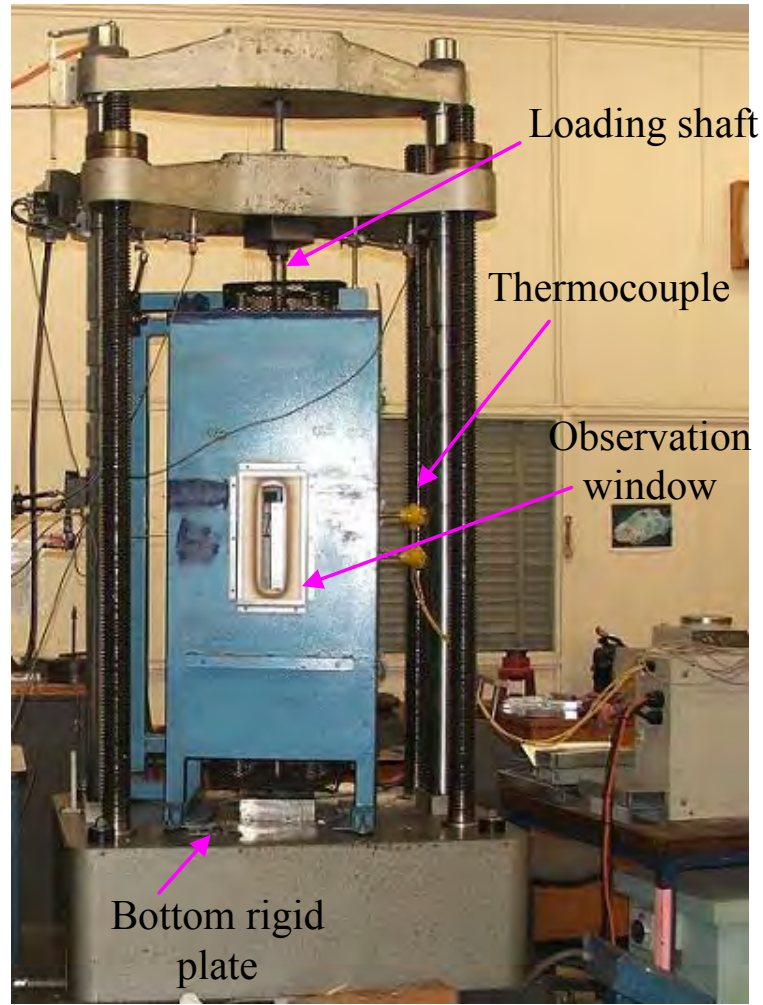

(a) Electric furnace and loading set-up

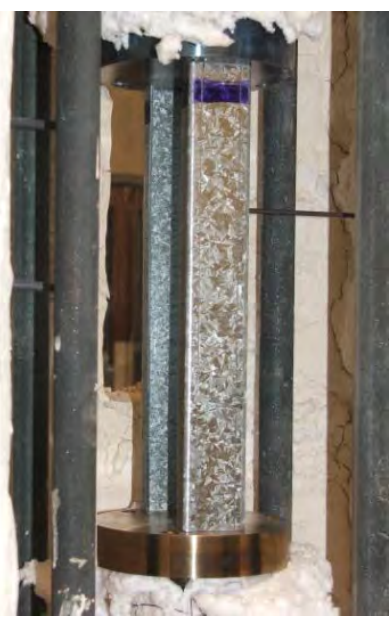

(b) Glow bars

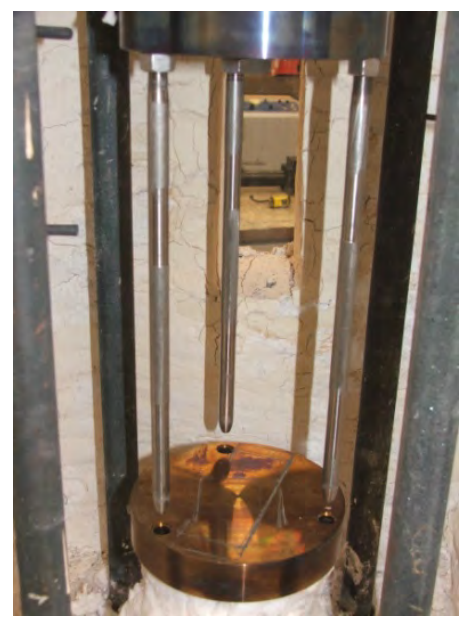

(c) Alignment of loading shafts

Figure 5: Test Set-up at Elevated Temperatures 


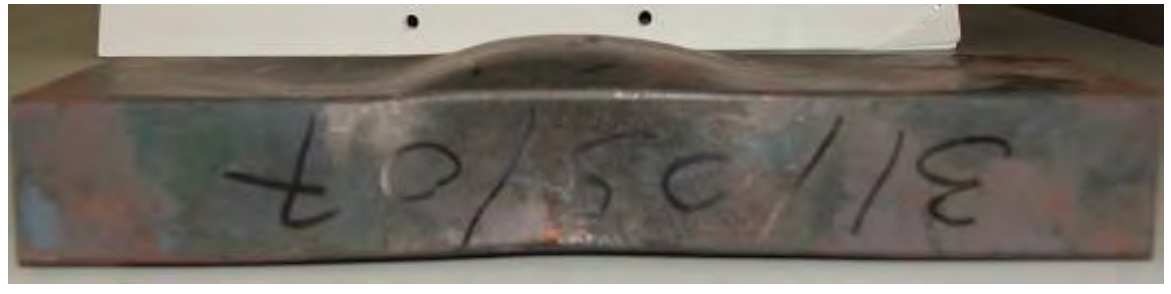

(a) Failure Mode of G550-0.95-700-A (local web buckling)

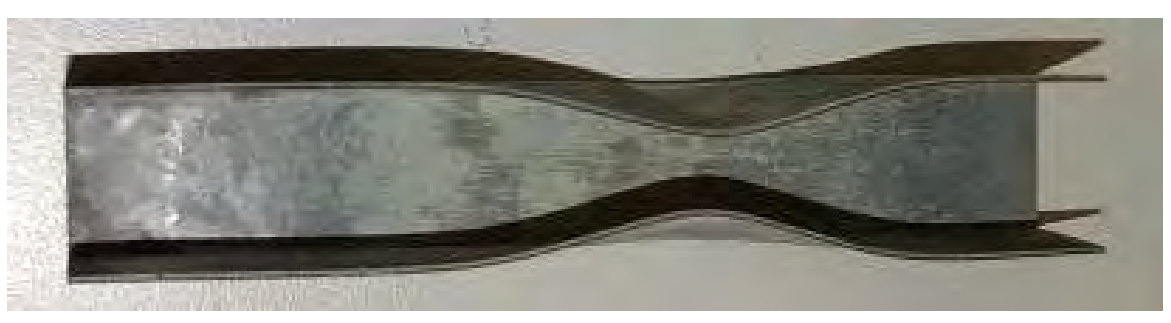

(b) Failure Mode of G550-0.95-700-B (local flange buckling)

Figure 6: Local Buckling Failures at Elevated Temperatures 


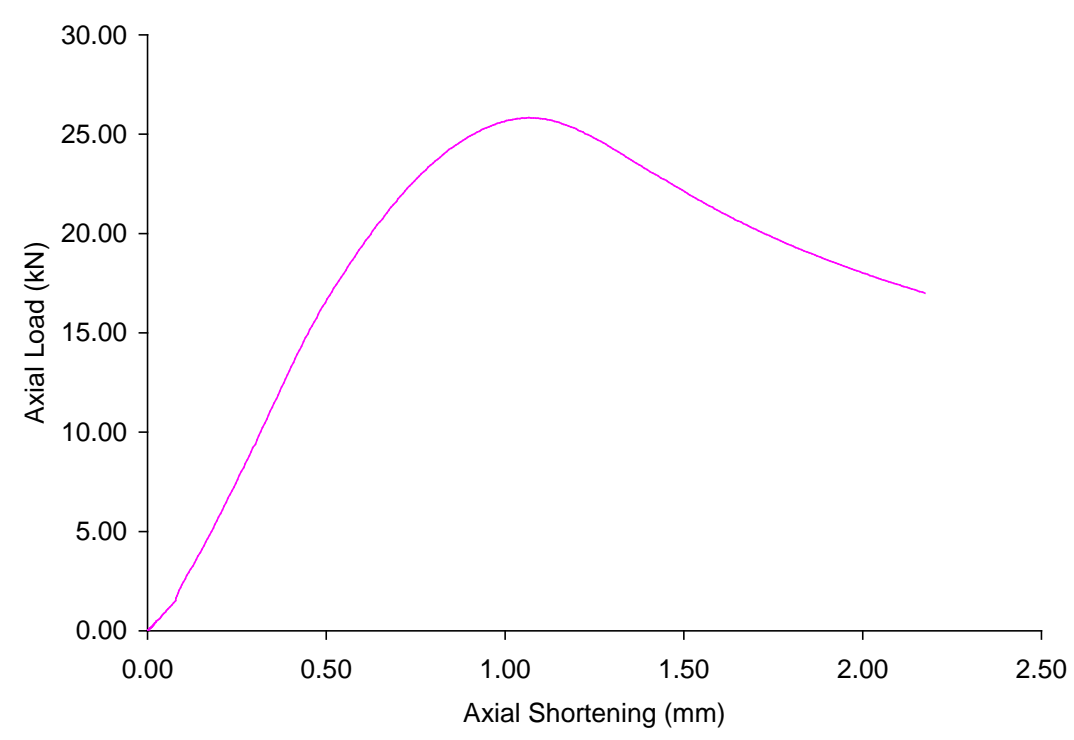

(a) Axial compression load versus axial shortening

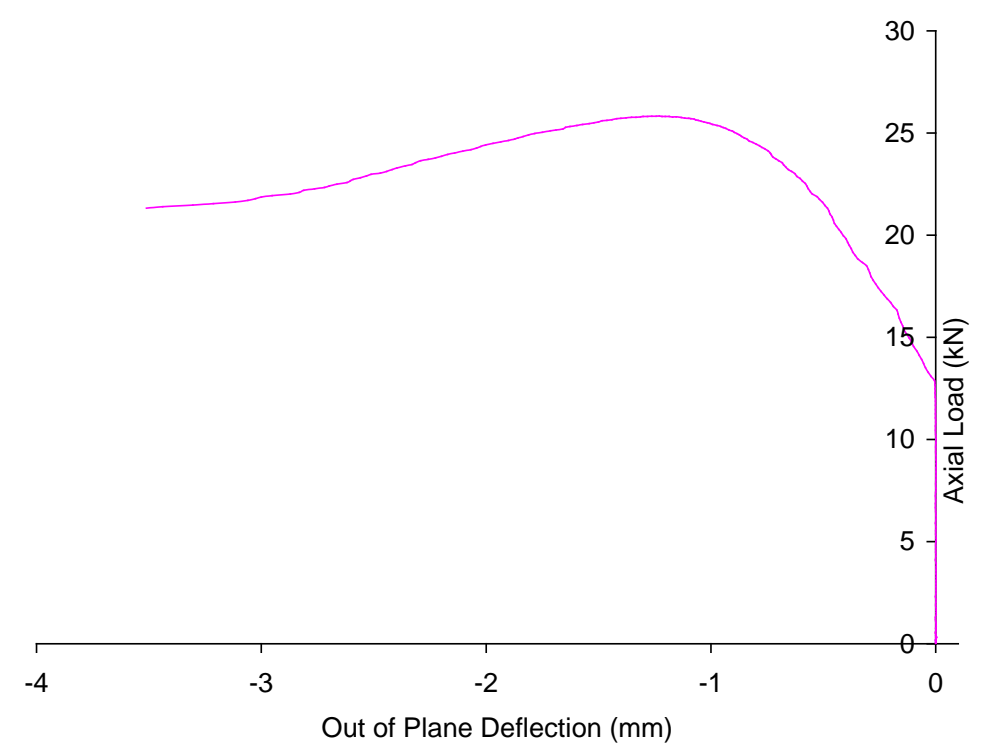

(b) Axial compression load versus out-of-plane deflection (flange)

Figure 7: Typical Load-Deflection Curves of G550-0.95-300-BSection 


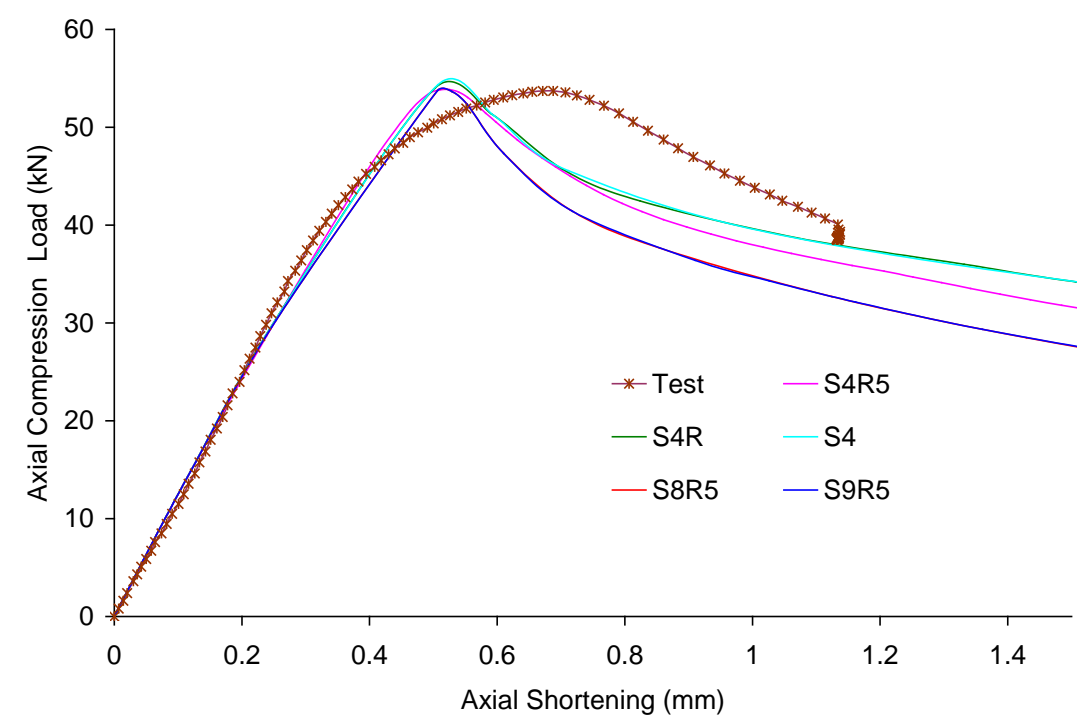

Figure 8: Load-Shortening Curves of G550-0.95-20-A Section from FEA Using Different Shell Element Types and Tests

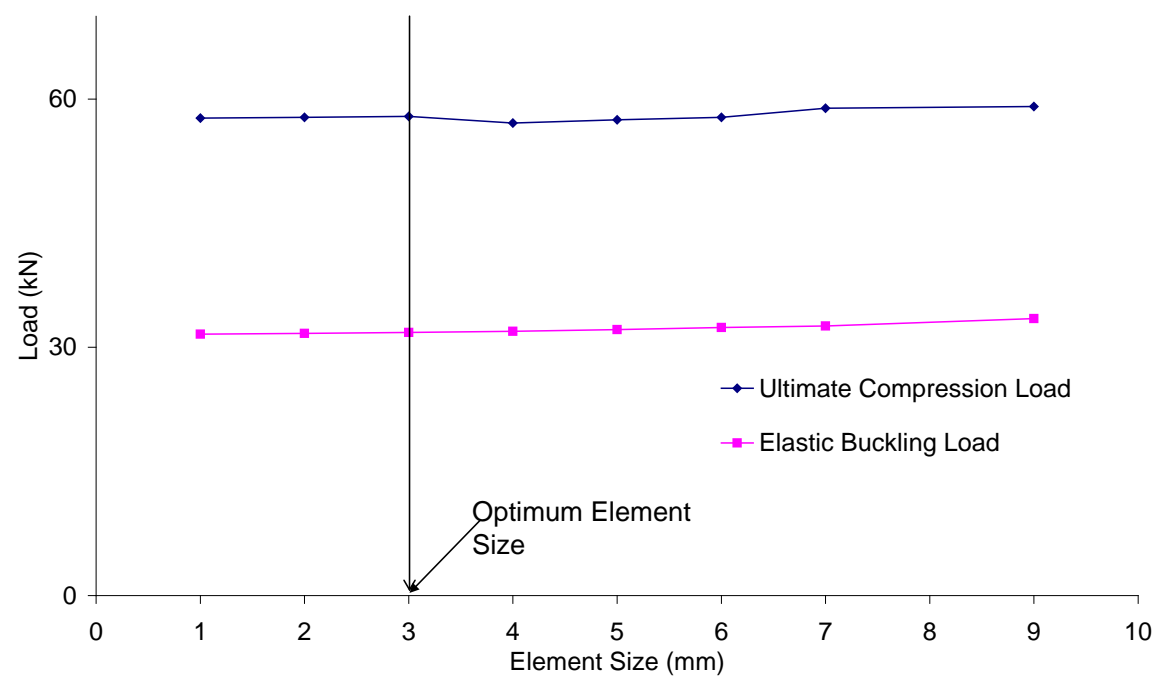

Figure 9: Effect of Element Size on Elastic Buckling and Ultimate Loads of G550-0.9520-A Section 


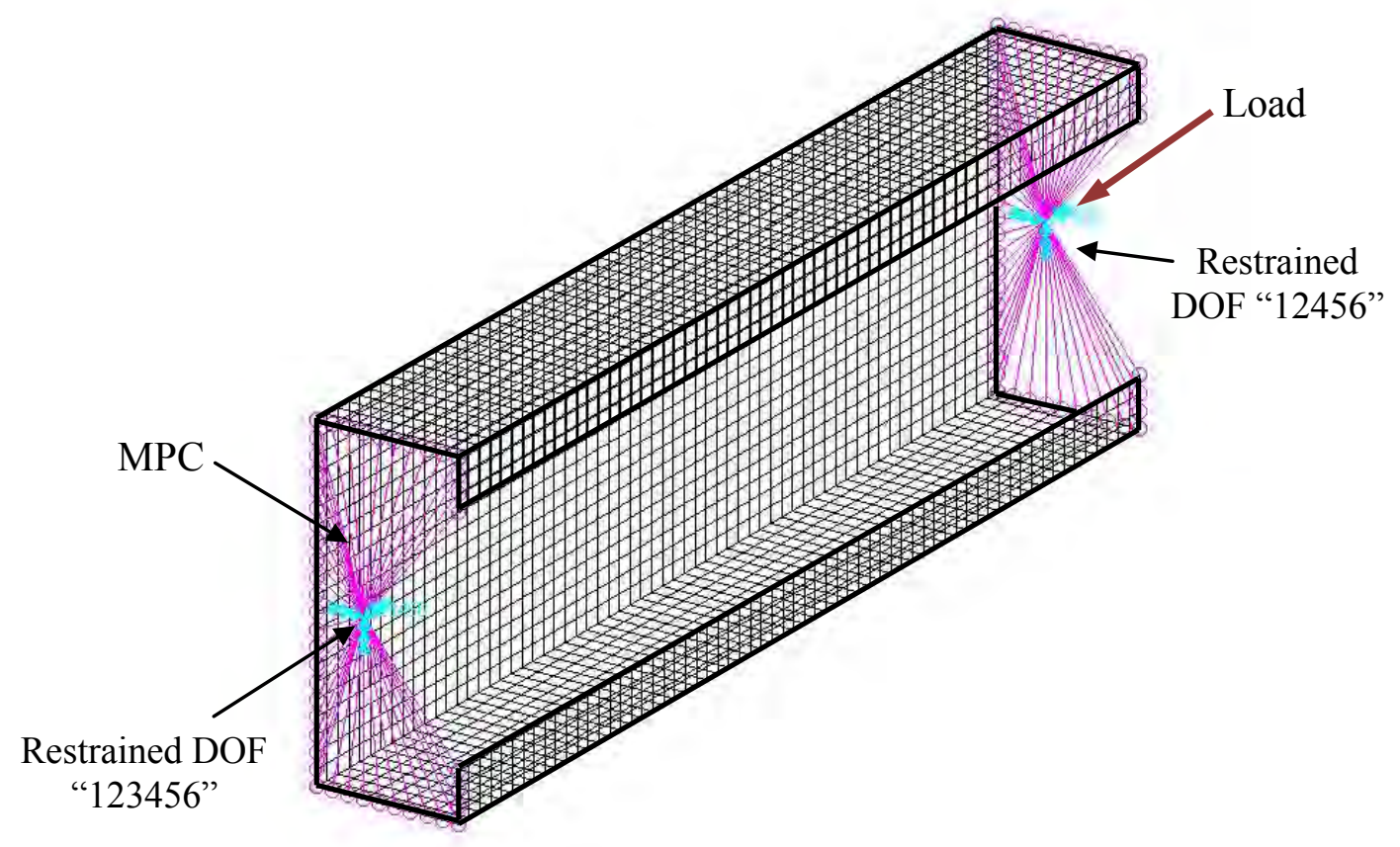

(a) Loading and boundary conditions

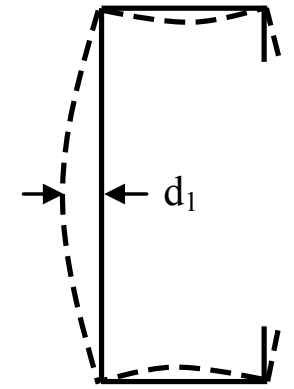

Type A section

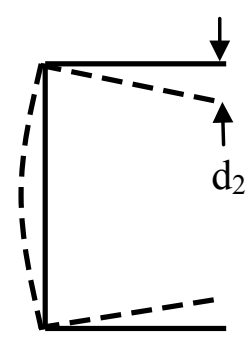

(b) Geometric imperfection

Figure 10: Finite Element Model of Lipped Channel Column 


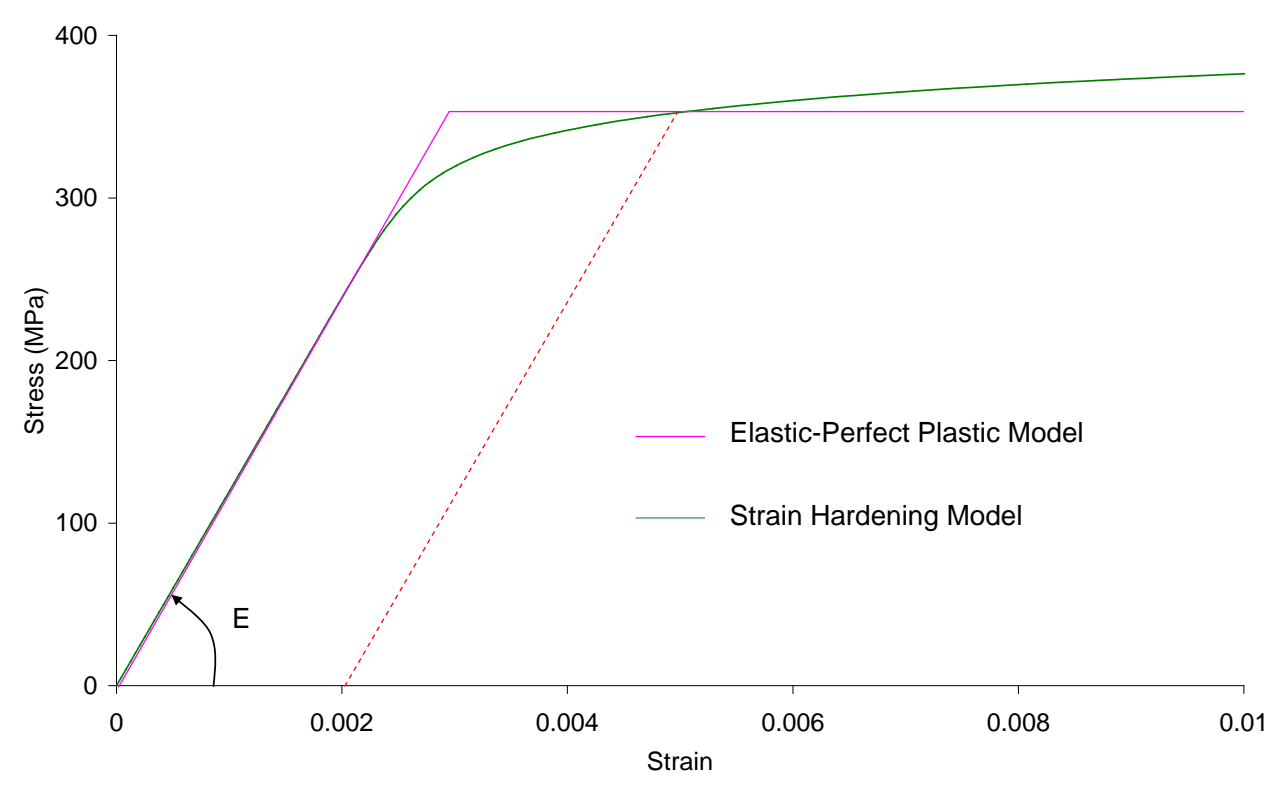

Figure 11: Stress-Strain Models 


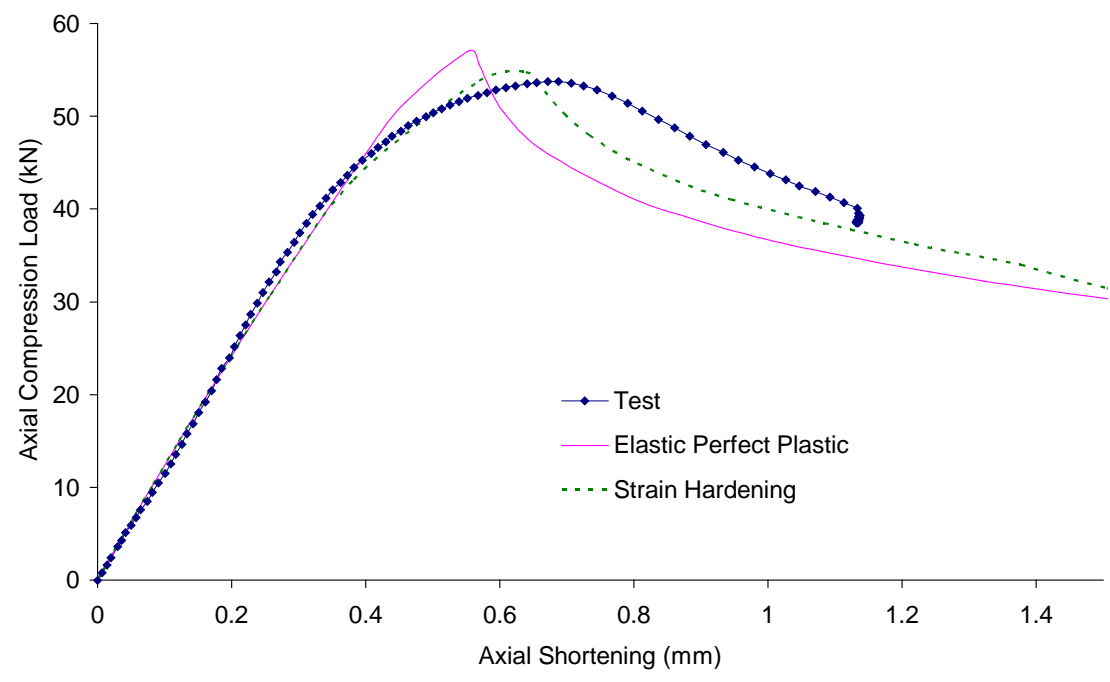

(c) At ambient temperature

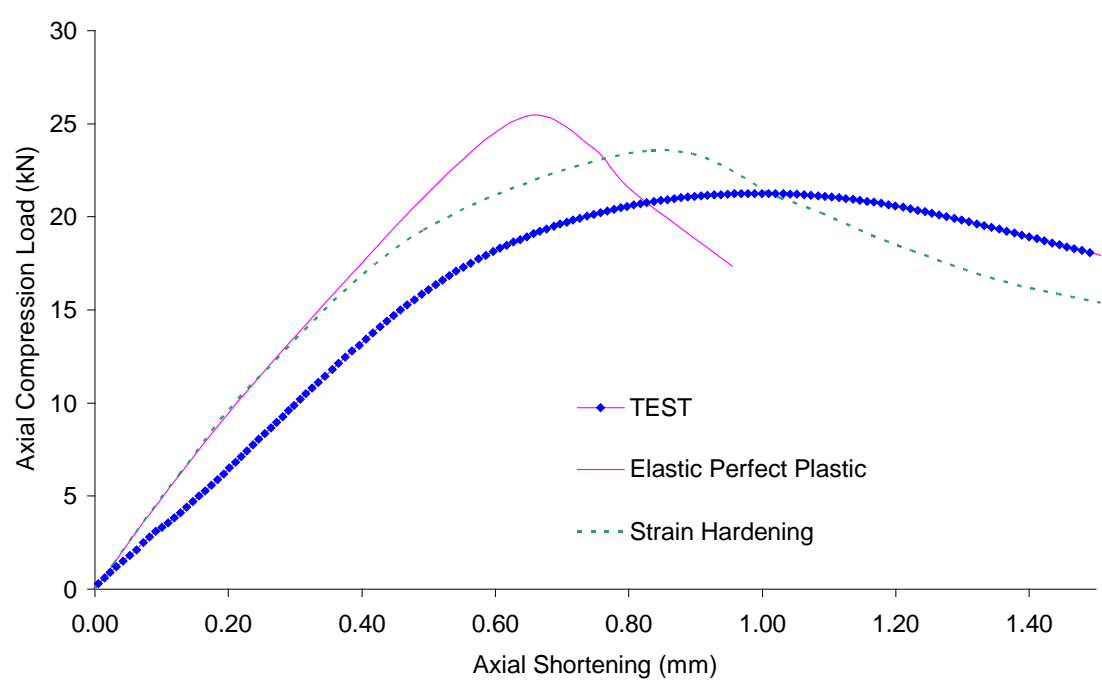

(b) At $500^{\circ} \mathrm{C}$

Figure 12: Load-Shortening Curves of G550-0.95-A Specimens from FEA with Different Mechanical Property Models and Tests 


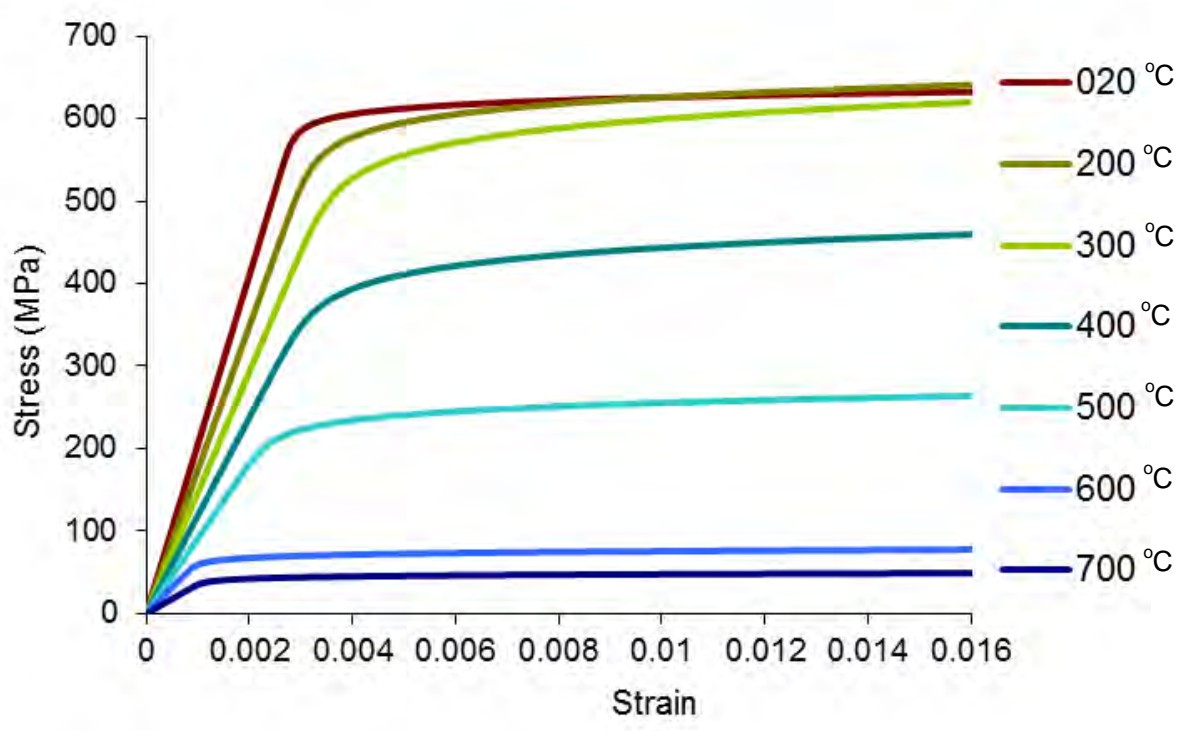

(a) G550-0.95 $\mathrm{mm}$ steel

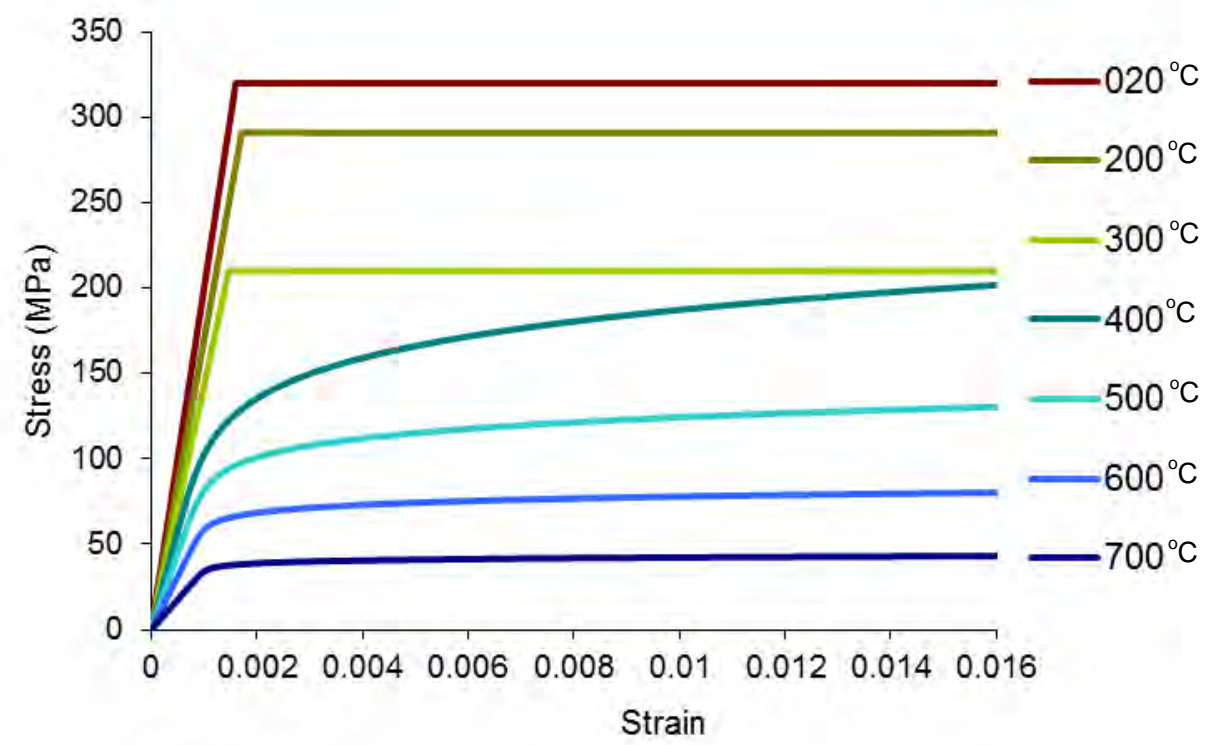

(b) G250-0.95 $\mathrm{mm}$ steel

Figure 13: Stress-strain Curves at Elevated Temperatures 


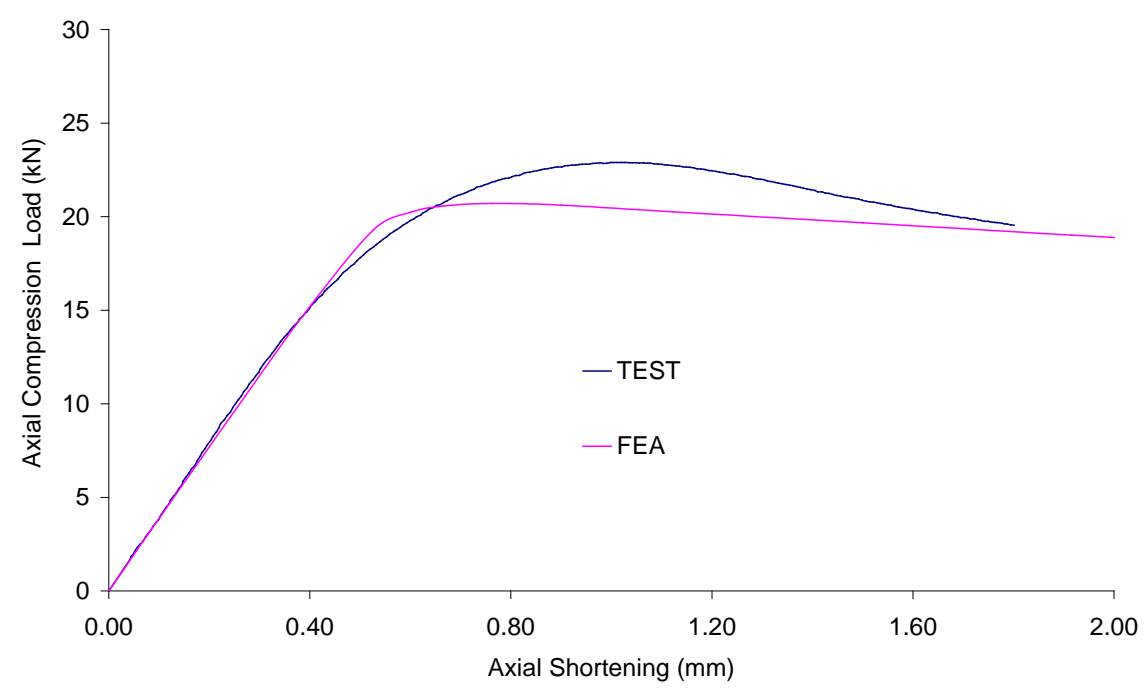

(a) G250-1.95-600-A section

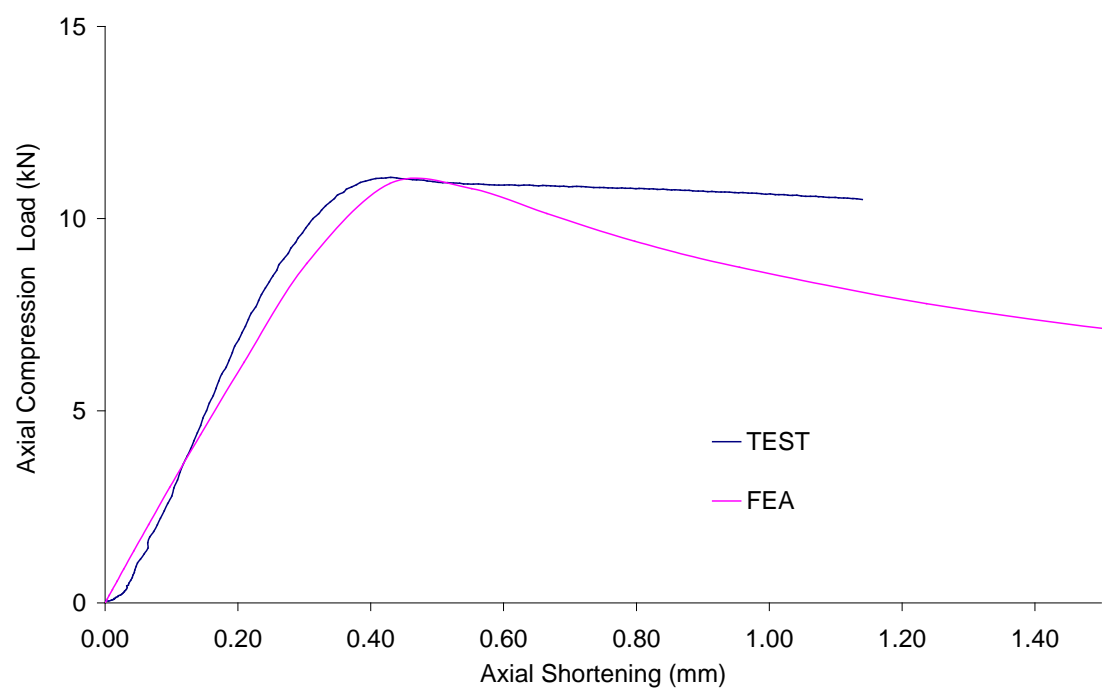

(b) G250-0.95-300-B section

Figure 14: Comparison of Load-Shortening Curves from Tests and FEA 

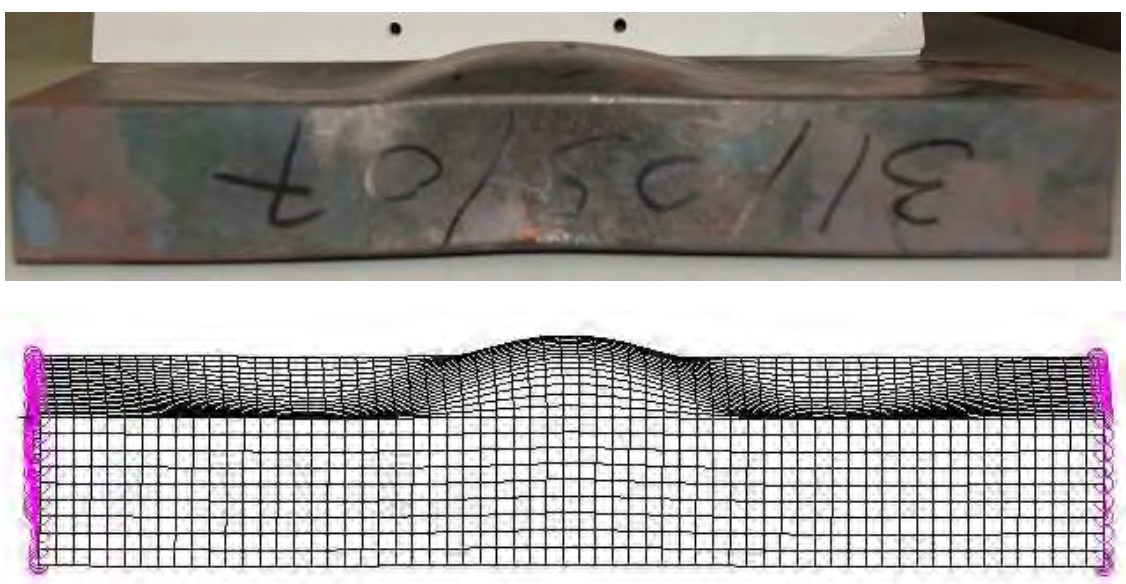

(a) G550-0.95-700-A specimen

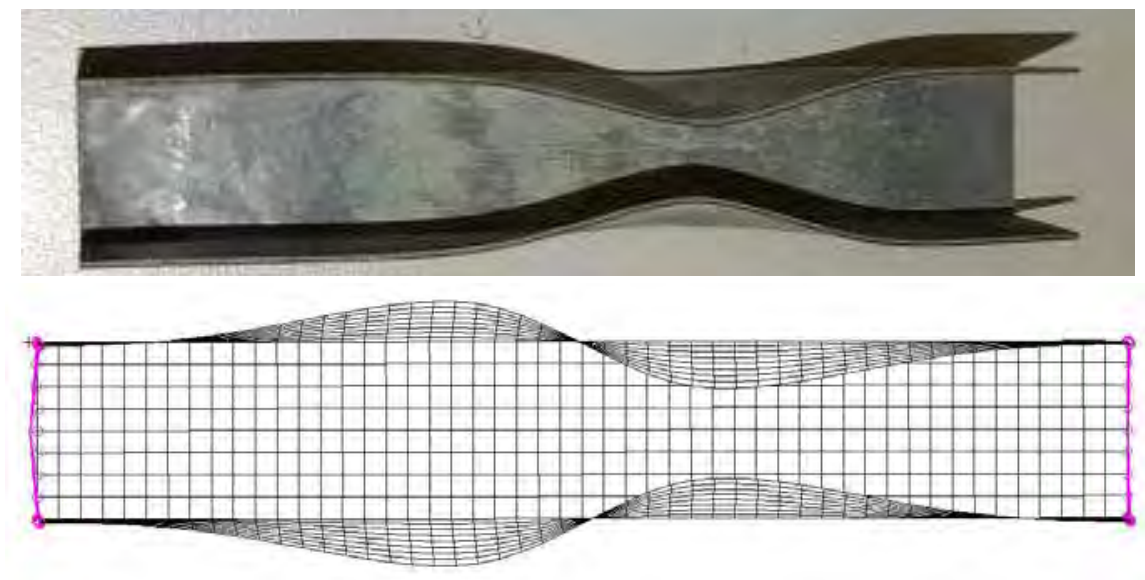

(b) G550-0.95-700-B specimen

Figure 15: Comparison of Failure Modes from Tests and FEA 


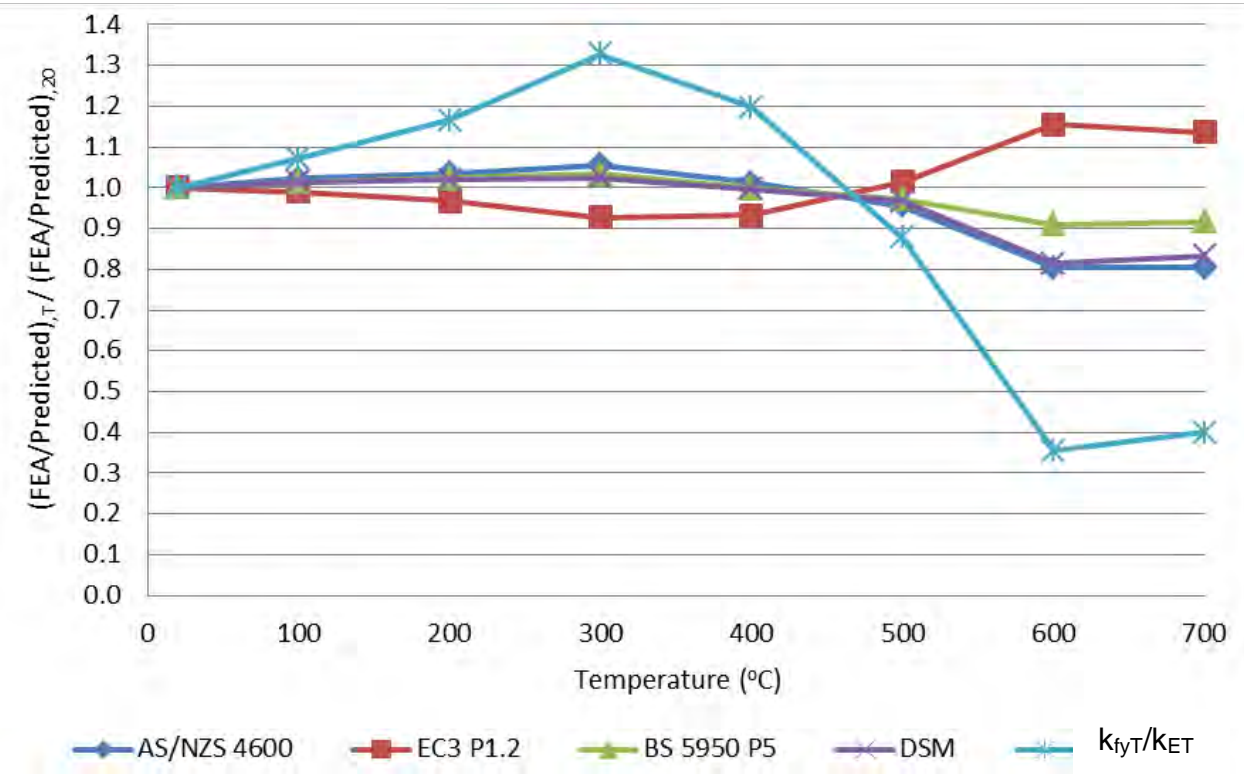

(a) G550-0.95-A section

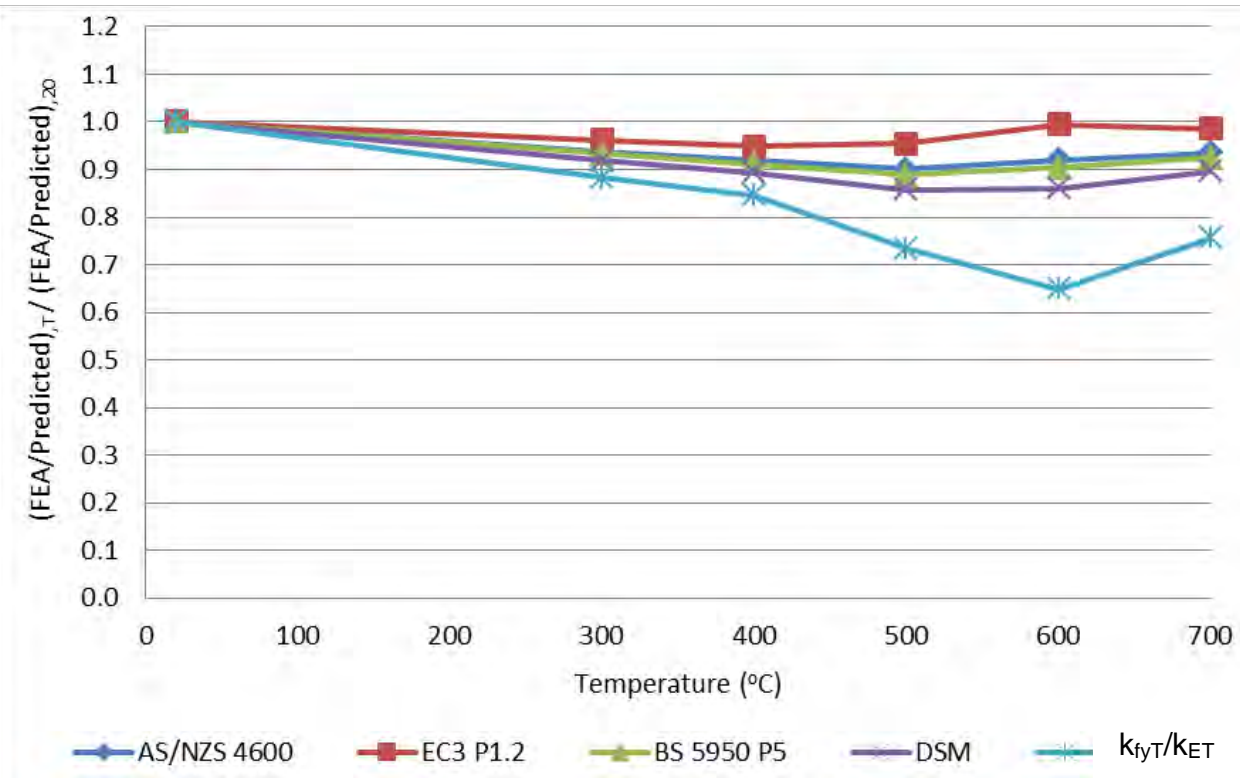

(b) G250-1.95-A section

Figure 16: Comparison of Different Standards with Temperatures 


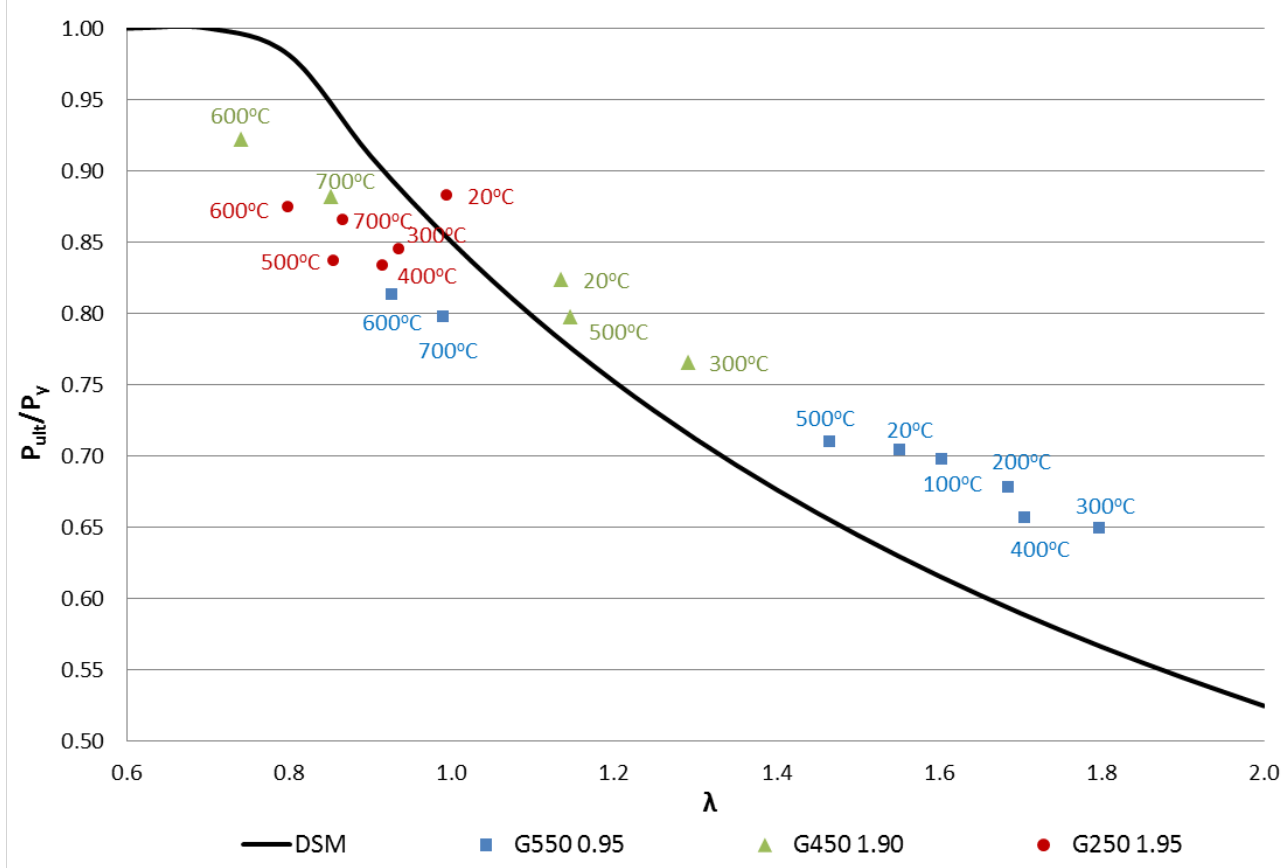

(a) Type A sections

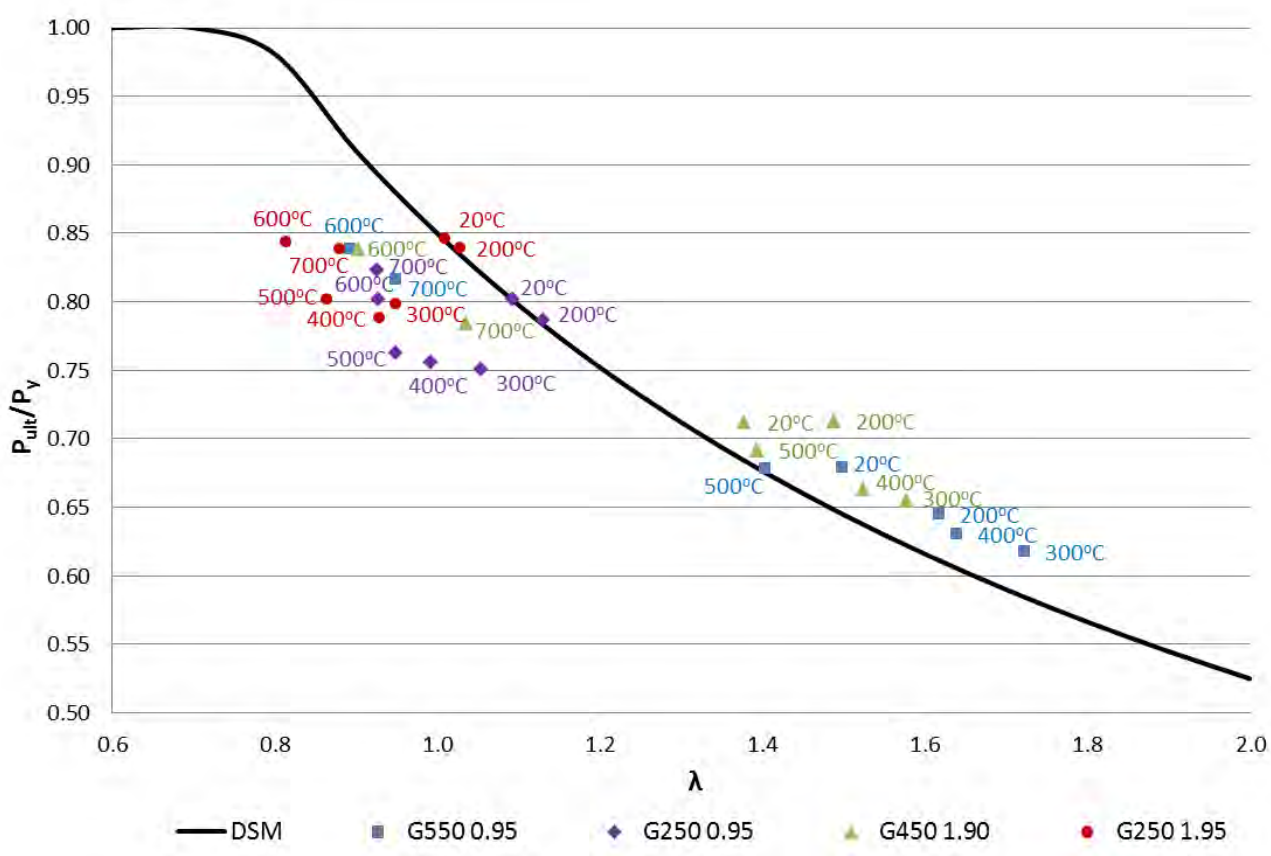

(b) Type B sections

Figure 17: Comparison of Ultimate Load Results with DSM Design Curve 